Article

\title{
How Frugal Innovation Promotes Social Sustainability
}

\author{
Rakhshanda Khan
}

LUT School of Business and Management, Lappeenranta University of Technology, Lahti 15140, Finland; rakhshanda.khan@lut.fi; Tel.: +358-408-225-592

Academic Editor: Yongrok Choi

Received: 27 June 2016; Accepted: 11 October 2016; Published: 15 October 2016

\begin{abstract}
There is a need to develop an understanding of how frugal innovation promotes social sustainability. The objective of this paper is to find the connections between the two concepts of social sustainability and frugal innovation, by reviewing the existing literature concerning both fields. This paper presents a framework that identifies essential themes of social sustainability and explores them through frugal innovation. The framework builds on the important themes of social sustainability and shows their relevance in practice through frugal innovation. The notion of frugal innovation can be viewed as an approach towards realizing social sustainability and fulfilling the United Nations' Sustainable Development Goals.
\end{abstract}

Keywords: social sustainability; frugal innovation; practice; Sustainable Development Goals

\section{Introduction}

Within the sustainability discourse, the social pillar is considered of utmost importance, alongside the other two pillars of sustainable development-environmental and economic. Social sustainability is focused on the development of programs and processes that promote social interaction and cultural enrichment. It emphasizes protecting the vulnerable while respecting social diversity and is related to more basic needs of happiness, safety, freedom, dignity and affection [1]. Notably, the key challenges of sustainable development reside at the interfaces and trade-offs between its various dimensions [2]. Therefore, it is essential to develop the concept of social sustainability by adopting the integrating framework of sustainability [3]. Both the environmental and economic aspects of sustainable development are intertwined with the social pillar. For example, it is perhaps not possible to either achieve happiness in a society that is economically disadvantaged or have a healthy community if air quality is poor. According to Torjman [4], "human well-being cannot be sustained without a healthy environment and is equally unlikely in the absence of a vibrant economy".

Keeping the above principle in view, this paper seeks to highlight how social sustainability is strongly linked to frugal innovation. "Frugal innovation refers to products (both goods and services), processes, or marketing and organizational methods that seek to minimize the use of material and financial resources with the objective of reducing the cost of ownership while fulfilling or even exceeding certain pre-defined criteria of acceptable quality standards" [5]. Through frugal innovation, economically disadvantaged communities have been able to solve various problems pertaining to health, education or energy and uplift their standard of living. Frugal innovation has made a significant impact on society because it has aimed to solve pressing societal problems through ingenuity while simultaneously generating revenue. It has been argued before that businesses can play a critical role towards achieving sustainable development [6,7] and do untold good for the society [8]. Furthermore, frugal innovation has the potential to improve a company's sustainability performance [9]. However, the social benefits that frugal innovation can offer to the society have not been discussed considerably.

The objective of this paper is to find the connections between the two concepts of social sustainability and frugal innovation, by reviewing the existing literature concerning both fields. 
The researcher argues that the role of frugal innovation towards sustainable development should be studied in depth, better tools should be formed to analyze their relationship [10]; and a strong link should be established between the two concepts. Therefore, it is useful to link the concept of social sustainability empirically to frugal innovation as this connection will further broaden our understanding of the role of frugal innovation towards the promotion of Sustainable Development Goals (SDGs) especially concerning social sustainability. This article contributes to establishing connections by presenting a framework for understanding the link between social sustainability and frugal innovation.

The remainder of this paper is structured as follows: In the next section, the methodological approach is discussed. Section 3 gives an overview of the two important concepts: social sustainability and frugal innovation. Based on the social sustainability and frugal innovation literature, the argument for linking the two concepts is then justified. This section presents various examples of frugal innovations and shows their connection to the themes of social sustainability and SDGs. Thereafter, implications for theory and practice are discussed in Section 4 and the conclusion and future research directions are discussed in Section 5. For the purpose of this paper, the researcher has chosen Littig and Grießler's definition of social sustainability [11] which is described later in this paper and Tiwari and Herstatt's definition of frugal innovation [5] which is already described in the introduction.

\section{Materials and Methods}

A large volume of literature was scanned but a limited number of documents were reviewed and critiqued depending upon their applicability to the topic in discussion. The documents were selected from the social sustainability and frugal innovation literature. The aim was not to read everything written on the topic but to review a representative sample of papers from both bodies of literature in order to gain a sufficient understanding of the topics and establish connections. Two main databases were chosen for this research which include the Web of Science and Scopus. The initial search was undertaken using basic keywords in the beginning of January 2016. The study of the existing body of knowledge concerning two topics-social sustainability and frugal innovation-has been carried out systematically. Figure 1 shows the relative publication volume related to frugal innovation and social sustainability derived from Web of Science Core Collection. It is interesting to note that both the fields of literature have grown exponentially in the last couple of years. It is evident that there has been an increasing interest in both the fields of frugal innovation and social sustainability.

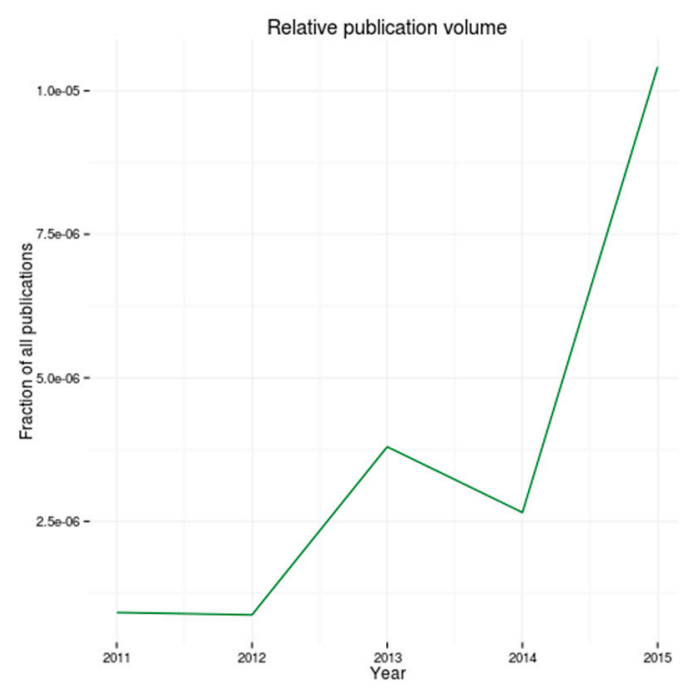

(a)

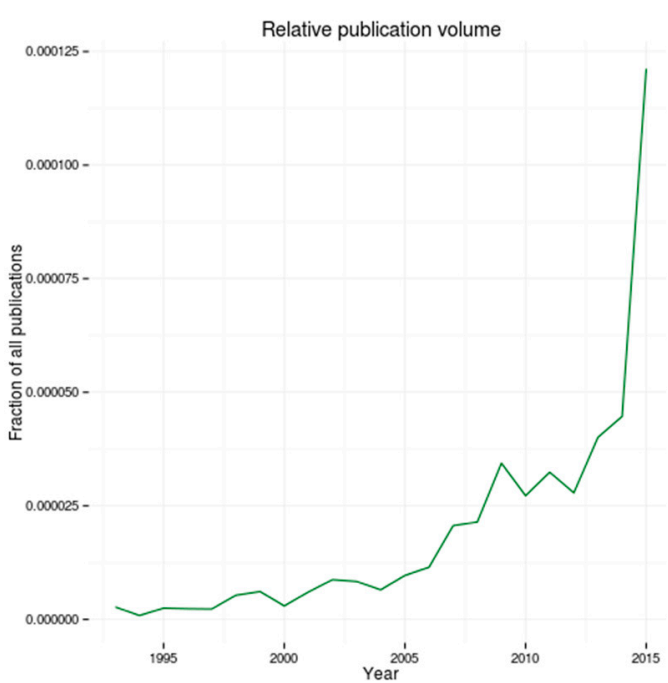

(b)

Figure 1. The relative publication volume related to frugal innovation (a) and social sustainability (b), as found in the Web of Science Core Collection. 
Therefore, a systematic study was carried out regarding the above mentioned topics in three main steps: (1) material collection; (2) material selection; and (3) material analysis. These three phases are described in the following paragraphs.

\subsection{Material Collection}

In this step, the researcher aimed at identifying all the relevant material concerning frugal innovation and social sustainability. The main keywords searched in frugal innovation publications included 'frugal innovation', 'jugaad innovation', 'bottom of pyramid (BOP) innovation' and 'reverse innovation' because the publications related to these terms are central to the concept of frugal innovation. For publications about social sustainability, the search was conducted using the keywords 'social sustainability', 'social sustainability definitions' and 'social dimension of sustainability'.

The researcher also reviewed reference lists from articles to find additional material not previously identified and searched for working papers to explore recent issues regarding these topics. The researcher also identified the relevant studies by searching the journals that were most cited while using the terms frugal innovation and social sustainability according to the Web of Science. Figure 2 lists the most popular publications that included articles on frugal innovation and social sustainability.

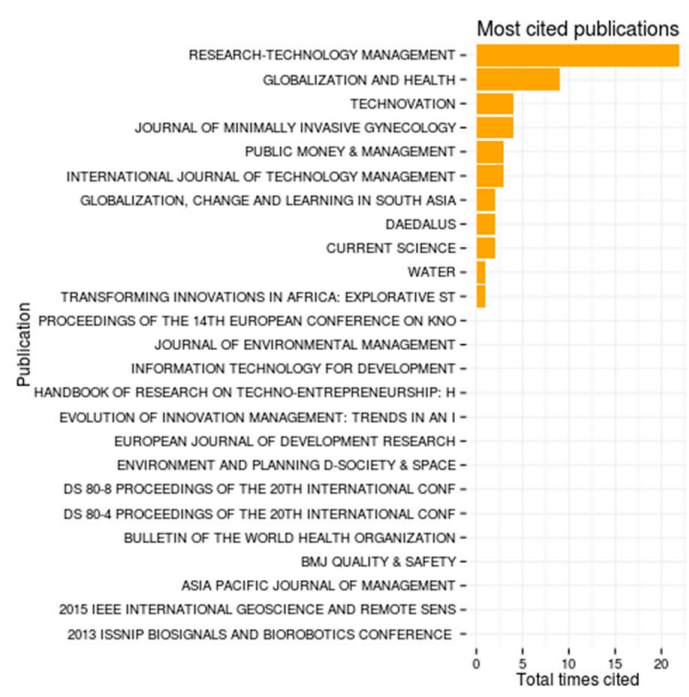

(a)

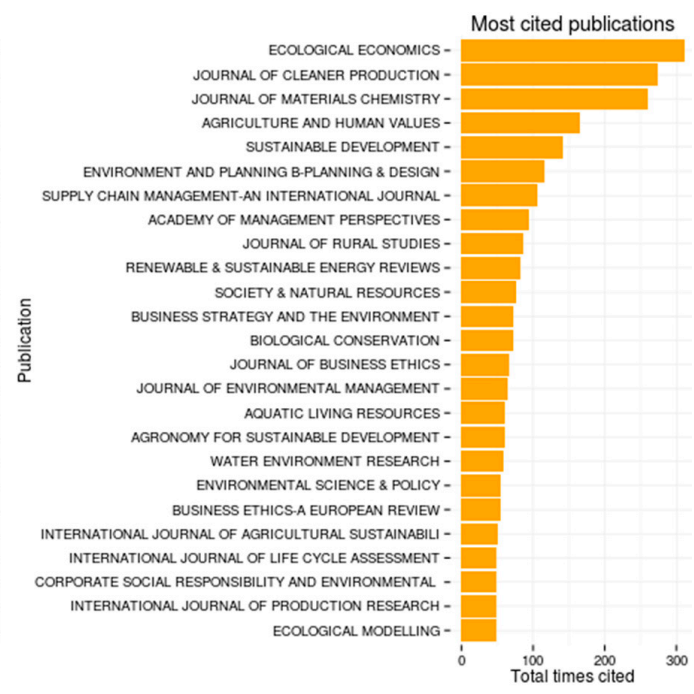

(b)

Figure 2. The most cited publications on frugal innovation (a) and social sustainability (b) in Web of Science Core Collection.

Finally, 104 records for frugal innovation and 1593 records for social sustainability literature were identified thereby making the total count of 1697 papers.

\subsection{Material Selection}

An analysis was performed by reading through the titles and abstracts of the 1697 publications. The abstracts were reviewed to determine whether or not the publications were relevant to the topics in question. Repetitive records as well as multiple irrelevant publications were found. A large number of documents were from diverse fields, such as healthcare, agriculture, sports or operations management, using the term 'social sustainability' in the title. Such papers dealt with different research fields and did not address social sustainability. For this reason, most of such papers were excluded. Numerous articles tackled sustainability at a general level, incorporating environmental and economic sustainability perspectives in particular, even with 'social sustainability' as the search term. A large volume of articles concerned topics such as renewable energy, smart grids, tourism sustainability, sustainable supply chain management, fisheries and other sustainability issues in 
general. Regarding frugal innovation, open innovation, crowdsourcing, product innovation, and other themes from the innovation management were also found, even though the search terms were precise. The researcher was primarily interested in those papers that helped with specifically understanding the nature and themes of social sustainability and frugal innovation. For frugal innovation publications, the aim was to select those publications that discussed the concepts/dimensions/characteristics of frugal innovation, jugaad innovation, BOP or reverse innovation through theory or practice. For social sustainability publications, the publication was expected to either understand or define the concept of the social dimension of sustainability, show its characteristics or its connections to other dimensions of sustainability.

At the end of this stage, all the perceived irrelevant publications were left out and 91 publications from social sustainability literature and 73 publications from frugal innovation literature were selected thereby making the total count of 164 publications. For the next step, two separate folders were created, one for each topic. All the relevant publications were downloaded in the folders. A set of relevant data was compiled that was thought to be suitable for the review.

\subsection{Material Analysis}

In this phase, the chosen publications were read carefully, and the characteristics and themes discussed in the frugal innovation literature and social sustainability literature were identified. The focus was on identifying the connections between the two bodies of literature. Important themes of social sustainability were derived from social sustainability literature. They were identified from the previous literature reviews and also from researcher's own analysis. These social sustainability themes were grouped together to form more profound themes. For example, themes such as 'equitable access to resources', 'equitable access to social services', 'equity' and 'equitable income distribution', were grouped together to form a larger theme called 'social justice and equity'. The aim was to limit the number of derived themes. In total, 23 themes were derived from the literature. Similarly, the characteristics of frugal innovations and their societal implications were also identified from the frugal innovation literature. The works of the authors involved in theorizing frugal innovation were limited. Most of the material dealt with studying individual examples; therefore, the researcher derived the characteristics of frugal innovation from the work of chosen authors. The next step was to show their societal implications by linking them to the themes of social sustainability.

Eight cases of frugal innovations were studied thoroughly and each case was evaluated according to the identified themes of social sustainability. The cases were selected based on three criteria. Firstly, these cases were prominent, having received significant media attention [12]. Secondly, as a group, they were selected to represent frugal innovations from a wide spectrum of organizations. For example, Aravind Eye Care and Narayana Hrudayalaya are hospital chains, Vortex Engineering (Solar Powered ATMs) is a medium sized firm, SELCO and Craftskills East Africa limited are social enterprises, Jaipur Foot is the product of a non-Governmental Organisation (NGO) and Kerala's palliative care is a charitable society. Lastly, they have all had a positive social impact.

\section{Results and Discussion}

\subsection{What Is Frugal Innovation?}

Frugal innovation is considered to be the future of the innovation management and a notion to look out for in the years to come [13,14]. The ultimate aim of innovation management is to create new concepts and move away from existing solutions [15]. Frugal innovation rethinks the nature of innovation. "It is an ability to do more with less by creating more business and social value while minimizing the use of resources such as energy, capital and time" [16]. Frugal innovation is developed in severe resource constraints; it involves good quality and reasonably priced products or services even for the customers with modest lifestyles. Frugal innovations are "good-enough, affordable products that meet the needs of resource-constrained consumers" [13]. 
Frugal innovation, which involves resource constrained product development, creates numerous benefits that are unavailable from traditional product development. It has the potential to enhance competitive advantage of a firm as well as green supply chain initiatives and be an ideal model to create green products [17]. Generally, frugal innovation is viewed as low cost innovation but it is much more than that. Frugal innovation uses the concept of simplification and strives for less instead of more by using clever technology. All the frugal solutions are characterized by affordability, robustness, user-friendliness, scalability and an attractive value proposition [18]. Frugal innovations are considered to be potentially disruptive and transformational [19] not only for emerging markets but also for developed markets [20].

Bhatti and Ventresca [21] combine historical and current analytical perspectives to define frugal innovation as means and ends to do more with less for more people. Frugal innovation as a term can act as an integrating mechanism to bring various concepts like disruptive innovation $[22,23]$ lean innovation [24], BOP [25] jugaad innovation [26], grassroot innovations [27] and inclusive innovations [28] under one umbrella [29].

The term reverse innovation is often used as a synonym for frugal innovation. However, even though they signify the same notion and are interrelated [30], there is a difference that distinguishes one from the other. "Reverse innovation refers to the case where an innovation is adopted first in poor (emerging) economies before 'trickling up' to rich countries" [31]. "Reverse innovations are always built on cost, good-enough, or frugal innovations" [14]. They are clean-slate innovations which means that they have to be developed from the scratch and it involves reversing the way companies approach innovation [32,33]. Agarwal and Brem [34] make the distinction that frugal innovation involves designing solutions specifically for low-income market segments, while reverse innovation involves new products developed in emerging markets, which are then modified for sale in developed countries. "The development of frugal product innovation capabilities is a critical success factor in the development of reverse innovation" [35]. The ability of a firm to exploit the potential of reverse innovation makes it more likely to succeed in global innovation [36].

Frugal innovation is also referred to as Jugaad innovation. Jugaad is a Hindi word that means creative improvisation (thinking in a frugal way and being flexible), which requires quick adaptation to uncertain circumstances in an intelligent way $[16,26,37]$. However, this term has a negative connotation among innovation scholars due to its meaning - a simple work around - and its usage as opposed to the mainstream innovation process $[38,39]$. Jugaad, at heart, is about a new model of innovation, which is based on constraints. It means solving a customer problem in the most innovative way when your resources are constrained. Brem and Wolfram [40] present a comprehensive definition of frugal innovation whereby they define it as a "derived management approach, based on jugaad, which focusses on development, production, and product management of resource saving products and services for people at BOP by achieving a sufficient level of taxonomy and avoiding needless costs".

For developing jugaad or in other words frugal innovations, unusual skillsets and mindsets are required. The most important characteristic of jugaad innovation is that it challenges the standard model of innovation, which involves highly structured and costly research to create new innovations [26]. It is characterized by limited resources to create low cost innovations that are sustainable for the environment and communities. These resource constrained product development strategies have the ability to give rise to products which are environmentally friendly due to lower resource use and greater supply chain efficiencies as compared to conventional product development approaches [17]. Jugaad is a way of survival for consumers at BOP [41].

BOP refers to the largest, and usually the poorest proportion of the world's population which constitutes an estimated four billion people in the developing world who live on less than $\$ 2$ per day [42]. The BOP markets are uncertain and volatile [43] and characterized by institutional voids [44]. However, BOP has the potential to offer opportunities to create value for both the companies and the poor [45-47]. Multinational corporations (MNC) ignore the BOP market and focus on existing markets as they view the BOP as unprofitable demographic [48]. However, Prahalad and Hart [25] suggest that 
it is possible to profit from the poor by treating them as self-respecting customers. These four billion micro consumers constitute a significant market and represent an engine of innovation, vitality, and growth [42]. By seeing poor as producers [49], co-producers of innovation [50,51], entrepreneurs or innovators [52,53] and not mere receivers, the firms can be successful in the BOP markets. Employing strategies like building local capacity and co-inventing custom solutions with non-traditional partners, these companies and their sustainable innovations can enter the BOP markets with ease [51,54]. Further, the lessons these established companies learn in BOP markets will serve them well in becoming globally competitive [55] and open the way to sustainable growth for the global economy [22]. According to Prahalad and Mashelkar [56], affordability and sustainability replace abundance and premium pricing as drivers for innovation in the developing countries.

Developing frugal innovations for the BOP market requires ingenuity and vision. Be it through MNC or social enterprise, non-governmental organisation (NGO) or small and medium sized enterprise (SME), any kind of entrepreneurial activity at BOP can help eradicate poverty in an economically feasible way $[57,58]$ if the environment is conducive to meeting certain success criteria [59]. It requires an environment which begins with (a) understanding the fundamental needs of the BOP population; (b) creating an entrepreneurial eco-system that involves partnerships with other companies and the public sector; and (c) nurturing an 'innovation sandbox' that encourages new ideas [60]. Therefore, the strategies and processes that are delivered to this market have to cope with resource constraints and at the same time either maintain or improve societal, ecological and economic sustainability [21]. The firms that address strategic innovation in BOP markets and address the issues of product affordability, acceptability, availability and awareness can build enormous market value [61]. Over the years, BOP concept has provided a new direction to the thinking of the corporate world [62]. There has been a lot of discussion around poor donning different hats as consumers, entrepreneurs [63,64], producers or suppliers $[44,65]$ across BOP literature. However, viewing poor as value-conscious consumers and creative entrepreneurs in BOP has been subjected to intense criticism. Criticism includes arguments such as it "presents a romanticized view of the poor, grossly underemphasizes the critical role and responsibility of the state in poverty reduction and ignores the vulnerability of the poor and underemphasizes the employability of the poor" [49,66-68], "obscuring unequal power relations at different societal levels and painting an optimistic picture of win-win outcomes" [69].

Frugal solutions are capable of uplifting the standard of living of individual communities to the next better level [5]. According to Basu, Banerjee and Sweeny [70], "Frugal innovation is a design innovation process in which the needs and context of citizens in the developing world are put first in order to develop appropriate, adaptable, affordable and accessible services and products for the emerging markets".

The frugal mindset was created in emerging markets, especially India and China. Some scholars consider India to be the lead market for frugal innovation [5], while others are of the view that India's potential as a 'laboratory for frugal innovations' is over-rated [71]. Emerging markets have witnessed the frugal mindset for different reasons. Firstly, a large emerging market with a growing middle class and massive purchasing power had needs that were not being met. Their sensitivity concerning product pricing required manufacturers to innovate frugally and keep prices low. Secondly, the expensive workforce in the Western companies made it impossible to develop low cost products and innovate frugally. Thirdly, the manufacturers from emerging Asian markets, especially India and China, focused on the real needs of the customers as opposed to manufacturers in the West, who focused on the wants more than the needs of customers. Therefore, they could not innovate frugally for customers in emerging markets, and the gap was then conveniently filled by companies in emerging markets [72]. Lastly, extreme conditions and major gaps in service provision stimulated demand for low-cost solutions in health, education and energy [12].

The concept of frugal innovation is gaining momentum as the experts have realized that frugality has to be the mindset of every business firm operating in the emerging markets or the developed world. Frugal innovations are becoming popular in developed economies due to their lower costs and no frills 
structure [73]. In order to succeed in the emerging markets, the Western companies have to change their approach to innovation. So far, innovation has meant the development of new products with more advanced features at premium prices. However, in emerging markets, companies need to master the art of frugal innovation as economically disadvantaged people are extremely price sensitive [74]. Stripping products of non-essential features and applying sophisticated technologies in order to reduce costs and adopt products to local environments makes the difference between failure and success of such innovations [20]. Therefore, instead of offering outdated technologies from Western markets to emerging markets at lower prices, Western companies need to produce frugal innovations from scratch. These frugal innovators must devise low-cost strategies to handle resource limitations when innovating, developing and delivering products and services to low-income users in emerging markets, where affordability, resources and institutional constraints exist [75]. Frugal innovators need to build innovation capabilities by creating an innovation process that overcomes 'the deficiency problem' in generating cheap priced original products [76]. A frugal mindset is encouraged not only by a resource scarce environment but also a higher tolerance for uncertainty [77]. Poor customers in the rich countries also need to be served; to do so, a frugal mindset associated with BOP strategies must be instilled in firms' business models [78]. There are many reasons for the developed world to embrace frugal innovations which include (a) slow growth in developed economies, which will increase demand for frugal innovations; (b) environmental constraints, which will increase demand for more frugal models of production and consumption; (c) caring for rapidly aging societies, which will require new and frugal approaches to health and social care; (d) understanding that the fastest growing markets are in developing economies, where the demand for frugal products and services is high; therefore, there is a huge business opportunity for Western frugal innovators [12].

Table 1 identifies the characteristics of frugal innovations and also provides information about the societal implications. The purpose of Table 1 is to give a general idea about the characteristics of frugal innovations included in the literature. It also highlights the importance of societal benefits that result from frugal innovations.

Table 1. Characteristics of frugal innovation and implications for society-from the frugal innovation literature.

\begin{tabular}{|c|c|c|}
\hline Author & Characteristics & Implications for Society \\
\hline Prahalad [42] & $\begin{array}{l}\text { Price Performance } \\
\text { Innovation: Hybrids } \\
\text { Scale of operations } \\
\text { Eco-friendly } \\
\text { Identifying functionality } \\
\text { Process innovation } \\
\text { Deskilling of work } \\
\text { Education of customers } \\
\text { Designing for hostile infrastructure } \\
\text { Interfaces } \\
\text { Distribution: accessing the customer } \\
\text { Unconventional way to deliver products }\end{array}$ & $\begin{array}{l}\text { Making four billion poor people as customers } \\
\text { and treating them as self-respecting citizens } \\
\text { by understanding the fundamental needs of } \\
\text { the BOP population and innovating for them. } \\
\text { Building capacity for people to escape } \\
\text { poverty and deprivation. } \\
\text { Tackles basic needs, social inclusion, human } \\
\text { dignity, participation. }\end{array}$ \\
\hline $\begin{array}{l}\text { Tiwari and } \\
\text { Herstatt [5] }\end{array}$ & $\begin{array}{l}\text { Affordable } \\
\text { Robust } \\
\text { User-friendly } \\
\text { Easy to use } \\
\text { Minimal use of raw materials } \\
\text { Acceptable quality standard }\end{array}$ & $\begin{array}{l}\text { Uplifting the standard of living of individual } \\
\text { communities to the next better level. } \\
\text { Tackles human well-being, quality of life, } \\
\text { dealing with poverty. }\end{array}$ \\
\hline
\end{tabular}


Table 1. Cont.

\begin{tabular}{|c|c|c|}
\hline Author & Characteristics & Implications for Society \\
\hline $\begin{array}{l}\text { Basu, Banerjee } \\
\text { and Sweeny [70] }\end{array}$ & $\begin{array}{l}\text { Ruggedization } \\
\text { Light weight } \\
\text { Mobile enabled solutions } \\
\text { Human centric design } \\
\text { Simplification } \\
\text { New distribution models } \\
\text { Adaptation } \\
\text { Use of local resources } \\
\text { Green technology } \\
\text { Affordability }\end{array}$ & $\begin{array}{l}\text { Needs and context of poor citizens in the } \\
\text { developing world are put first in order to } \\
\text { develop appropriate, adaptable, affordable } \\
\text { and accessible solutions for them. } \\
\text { Tackles social coherence, equity, social justice. }\end{array}$ \\
\hline $\begin{array}{l}\text { Rajdou, Prabhu } \\
\text { and Ahuja [26] }\end{array}$ & $\begin{array}{l}\text { Creative improvisation } \\
\text { Innovation based on constraints } \\
\text { Unusual skillset and mindset } \\
\text { Flexibility } \\
\text { Simplicity } \\
\text { Social Inclusion }\end{array}$ & $\begin{array}{l}\text { Innovating for the margins of the society and } \\
\text { bringing them into the mainstream. } \\
\text { Tackles social inclusion, social justice. }\end{array}$ \\
\hline Rao [73] & $\begin{array}{l}\text { No frills, low cost products/services } \\
\text { robust, sustainable design, ease of use, } \\
\text { Strong tendency to disrupt incumbents. }\end{array}$ & $\begin{array}{l}\text { Innovating to harness frugality and improve } \\
\text { profitability in a world conscious of cost } \\
\text { and sustainability. } \\
\text { Tackles human well-being and dealing } \\
\text { with poverty. }\end{array}$ \\
\hline $\begin{array}{l}\text { Govindarajan and } \\
\text { Trimble [32] }\end{array}$ & $\begin{array}{l}\text { Clean-slate innovations (developed from } \\
\text { scratch in the developing world) }\end{array}$ & $\begin{array}{l}\text { Closing the wide gaps between the rich and } \\
\text { the poor world. } \\
\text { Tackles equity and social justice. }\end{array}$ \\
\hline
\end{tabular}

\subsection{What Is Social Sustainability?}

Sustainable development recognizes the interdependence of environmental, social, and economic systems - the three pillars of sustainability which have appeared to understand, address and reduce current, and future potential problems $[79,80]$. However, achieving a balance between these three pillars is the need of the hour [81]. The social pillar has not received as much attention as the other two dimensions-ecological and economic [1,82-87]. Therefore, it is important to explore the role of organizations that organize the sustainability projects in shaping the balance between the pillars [88,89]. Nevertheless, social sustainability is considered to be the fundamental component of sustainable development [90]. Social sustainability is a multifaceted concept which has often been studied through the lenses of separate disciplines and theoretical perspectives [91,92]. It is a dynamic concept with a high possibility of change over time. It is unclear what social sustainability really means in practice and what its dynamics and breaks are [11,88,92-95].

Spangenberg and Omann [84] identified three analytical views that surround the social sustainability discussions. They include functional approach-popular in studies of rural, urban or community sustainability, capital approach—views from economic thinking, and system approach-views each domain as a system that should be capable of reproduction. During the last 15 years, many researches around social sustainability have focused mainly on the urban studies from both academic and policy perspectives [96]. Weingaertner and Moberg [91] reviewed social sustainability from the perspectives of urban development and the viewpoint of companies and products and identified that context dependency influences the relevance and interpretations of detailed aspects of social sustainability.

Many definitions of social sustainability have emerged so far, but its all-encompassing definition is still missing in policy and practice [96,97]. Sachs [98] states that "social sustainability must rest on the basic values of equity and democracy, the latter meant as the effective appropriation of all human rights—political, civil, economic, social and cultural—by all people". From a sociological standpoint, Littig and Grießler [11] state that "social sustainability is given, if work within a society and the related 
institutional reproductive capabilities are preserved over a long period of time and the normative claims of social justice, human dignity and participation are fulfilled". Polese and Stren [99] stated, "social sustainability of a city is defined as development that is compatible with harmonious evolution of civil society, fostering an environment conducive to the compatible cohabitation of culturally and socially diverse groups and encouraging social integration, with improvements in the quality of life for all segments of the population".

One important focus of the definitions of social sustainability is future generations, in that improvement of a society should allow current and future generations to utilize social resources in a healthy way. According to Western Australia Council of Social Services, "Social sustainability occurs when the formal and informal processes, systems, structures, and relationships actively support the capacity of current and future generations to create healthy and livable communities" [100]. Chiu [101] expands on the notion of well-being of generations taken from Brundtland's definition of sustainable development. Chiu [101] describes social sustainability as the maintenance and improvement of the well-being of current and future generations. Other authors do not provide a definition of social sustainability but suggest the main themes [102], which can be found later in this paper. During the last 10 years, the concept of social sustainability has shifted toward being seen as dependent on social networks, making community contributions, creating a sense of place and offering community stability and security [92,103].

Some authors focus on the attributes of a socially sustainable community. For instance, Vallance et al. [104] describe a socially sustainable community as the one that has certain key elements which include social homogeneity, equitable incomes, access to goods and services, employment and cultural as well as political sustainability. Such a community is equitable, diverse, connected, and democratic and provides a good quality of life [100]. In a more recent study, Missimer, Robert and Broman [105] state that, in a socially sustainable society, people are not subject to structural obstacles to health, influence, competence, impartiality and meaning-making.

Social sustainability is also related to more basic needs of happiness, safety, freedom and dignity [1]. Magis and Shinn [106] define four central constituents of social sustainability: human well-being, equity, democratic government, and democratic civil society. Human well-being ensures the protection of basic needs, equity ensures mechanisms to guarantee equitable sharing of society's benefits and costs, democratic government ensures that the governance is oriented to the people and the democratic society empowers people to build democratic government.

Larsen [107] states that, "Social sustainability must (a) build inclusion at the level of the individuals, groups and society; (b) provide for basic human dignity which includes at least basic human sustenance, freedom from tyranny, freedom of association, and basic human liberty; (c) provide a means for people to influence their governance; and (d) create the capacity for learning at the level of individuals, groups, collectives, governments, corporations and society".

Social sustainability is also viewed as a process. According to McKenzie [100], social sustainability is a life-enhancing condition within communities, and a process within communities that can achieve that condition and this condition can be achieved through several factors like equity of access to key services, diversity, political participation at local level, transmitting awareness of social sustainability from one generation to the next, mechanisms of community to fulfil its own needs and so on. In short, "social sustainability concerns how individuals, communities and societies live with each other and set out to achieve the objectives of development models they have chosen for themselves also taking into account the physical boundaries of their places and planet Earth as a whole" [90].

It has been argued that measuring and quantifying social sustainability has been quite challenging [2,108-110] as the indicators are less developed [111,112] because this concept is intangible and qualitative in nature [110] and there is no widely accepted scientific basis for analysis [113]. However, previously many scholars have developed indicators to assess social sustainability. For example, Spangenberg and Omann [84] refer to basic needs, social resources, equal opportunities, participation, sustaining oneself and cultural diversity as the most important indicators. Littig and 
Grießler [11] consider satisfaction of basic needs and quality of life, social justice, and social coherence as the three core indicators. Cuthill [82] considers social capital, social infrastructure, social justice and engaged governance as the key indicators of social sustainability. Vavik and Keitsch [1] stress three indicators, namely poverty, illiteracy and access. In a recent study, Tirado, Morales and Lobato-Calleros [114] refer to two indicators-efficiency and equity through which social sustainability can be best promoted. In yet another interesting study, scholars posit to add indicators that reflect the lived experience of disabled people [115]. However, scholars agree that a general consensus about the indicators has been difficult to reach due to its intangible nature and therefore, there is a need to quantify the already existing qualitative indicators $[84,110]$.

Missimer et al. $[105,116]$ even went a little further to question the existing framework for strategic decision making towards sustainability and demonstrated its dichotomies and lack of robustness in its social dimension and developed the 'Framework for Strategic Sustainable Development' which could be more cohesive and operational.

Social sustainability plays a strong role in business, and the role of socially driven businesses towards achieving social sustainability is also noteworthy. Currently, businesses are placing greater focus on social sustainability [117]. However, not much work has been done regarding social sustainability as it applies to business [118]. Therefore, more research that investigates the link between social sustainability and organizational effectiveness [119] should be done to obtain a better understanding of the links between business and society to fully address sustainable development [120] and, more importantly, its social dimension.

Theoretically, social sustainability as a concept covers broad societal issues [121] and has various interpretations in different fields [122]. Notably, regarding businesses, social sustainability is understood more generally as a business that influences individuals' or society's well-being $[110,123]$ or in other words, a system that meets the expectations of stakeholders without causing harm to the well-being of society and its members [124]. Here, the idea of social sustainability is commonly interpreted as the ability to continue to stay in business through good relations with stakeholders [125]. Social sustainability reflects the development that protects the mental and physical health of the stakeholders, leads to social development and treats all stakeholders fairly [1]. It covers the broadest aspects of business operations and the effects that they have on employees, customers, suppliers, investors, local and global communities. It also focuses on respecting social diversity [1].

It has been argued that businesses adopt top-down approaches to assess sustainability [126] and sometimes create fake reputations regarding their level of sustainability [127]. The indicators used to measure sustainability in overall business do not effectively address social criteria [128]. However, scholars are attempting to address this problem by devising most suitable standards to assess social sustainability in a business. For example, McElroy, Jorna and Engelen [129] have proposed a social footprint method to quantitatively measure and report on the social sustainability of their operations. Another set of standards was proposed by Thomsen and King [130] after evaluating the best business practices of sustainable businesses that could act as a starting point to assess social sustainability. These are workplace practices, work-life balance, retirement benefits, healthcare benefits, safe workspaces, stable housing, support services for children, support for employees in their non-work lives, training and support for the larger community. In recent years, impact investing has become quite popular among business leaders, government, social organisations and philanthropists who are interested in assessing social sustainability of businesses/projects in order to solve some of society's most pressing issues $[131,132]$. Many common frameworks are used by impact investors which include Impact Reporting and Investment Standards (IRIS), Global Impact Investing Rating System (GIIRS), Social Return on Investment (SROI), PULSE Impact Investing Management Software, Acumen Fund's Best Alternative Charitable Option, Endeavor's Impact Assessment Dashboard, etc. These social metrics are useful tools to evaluate the social or environmental impact of a business and serve as guides for impact investors. These metrics provide guidance to an impact investor while making 
investment decisions, identifying and mitigating risks, capturing long term value, tracking progress, improving the project/company, proving impact and attribution and reporting to stakeholders [133].

Businesses can help towards achieving social sustainability provided they fulfil the criteria of socially sustainable businesses. For instance, a socially sustainable business is that enterprise whose aim is to solve the pressing needs of society. It ensures that healthy relationships are maintained with all its stakeholders like employees, customers and community members. An interesting study by Galuppo et al. [134] has shown that building a socially sustainable business requires the management of multi-stakeholder processes that are often conflicting. Therefore, a socially sustainable business can contribute to the worthy goal of sustainability by crafting a "desirable future state for all stakeholders" [135]. It incorporates sustainability principles into everyday practices of a business [136] and, therefore, contributes towards the betterment of community and society at large.

Table 2 identifies the themes of social sustainability that different authors have highlighted thus far. The literature identifies the most important building blocks of what a socially sustainable society should entail. As it is evident from the table, numerous authors point towards similar themes as they remain the primary constituents of social sustainability. The purpose of Table 2 is to give an idea of the concepts included in various discussions of social sustainability. The literature outlined in Table 2 serves to identify what is generally understood by social sustainability.

Table 2. Themes of social sustainability derived from the social sustainability literature.

\begin{tabular}{|c|c|}
\hline Themes of Social Sustainability & Authors \\
\hline $\begin{array}{l}\text { Human health and } \\
\text { well-being/well-being of } \\
\text { generations }\end{array}$ & $\begin{array}{l}\text { Boström [137], Polese and Stren [99], Magis and Shinn, [106], Chiu [101], } \\
\text { McKenzie [100], Castillo et al. [138], Dempsey et al. [94], Gauthier [139], } \\
\text { Geibler et al. [110], Tanzil and Beloff [140], Colantonio and Dixon [141], } \\
\text { Rogers et al. [142], Partridge [3] }\end{array}$ \\
\hline Basic needs and quality of life & $\begin{array}{l}\text { Littig and Grießler [11], Polese and Stren [99], McKenzie [100], } \\
\text { Magis and Shinn [106], Spangenberg and Omann [84], Baines and } \\
\text { Morgan [143], Ancell and Thompson-Fawcett [144], Colantonio [102], } \\
\text { Dempsey et al. [94], Carew and Mitchell [145], Partridge [3] }\end{array}$ \\
\hline Social Coherence & $\begin{array}{l}\text { Littig and Grießler [11], McKenzie [100], Vallance, } \\
\text { Perkins and Dixon [104], Murphy [146] }\end{array}$ \\
\hline Social justice and equity & $\begin{array}{l}\text { Cuthill [82], Dempsey et al. [94], Littig and Grießler [11], } \\
\text { McKenzie [100], Magis and Shinn [106], Vallance, Perkins and } \\
\text { Dixon [104], Giddings, Hopwood and O'Brien [147], Spangenberg and } \\
\text { Omann [84], Murphy [146], Chambers and Conway [148], } \\
\text { Thin et al. [149], Koning [85], Chiu [101], Sachs [98], Holden [150], } \\
\text { Baines and Morgan [143], Polese and Stren [99], Partridge [3], } \\
\text { Ketschau [151] }\end{array}$ \\
\hline $\begin{array}{l}\text { Democratic/engaged government } \\
\text { and democratic society }\end{array}$ & $\begin{array}{l}\text { Cuthill [82], Magis and Shinn [106], Sachs [98], McKenzie [100], } \\
\text { Larsen [107], Davidson and Wilson [152], Dempsey et al. [94] }\end{array}$ \\
\hline Human rights & Bebbington and Dillard [113], Vavik and Keitsch [1], Sachs [98] \\
\hline Social inclusion & $\begin{array}{l}\text { Polese and Stren [99], Larsen [107], Davidson and Wilson [152], } \\
\text { Ancell and Thompson-Fawcett [144], McKenzie [100], } \\
\text { Dempsey et al. [94], Bramley and Power [153], Glasson and Wood [103], } \\
\text { Partridge [3] }\end{array}$ \\
\hline Diversity & $\begin{array}{l}\text { Vavik and Keitsch [1], Polese and Stren [99], McKenzie [100], } \\
\text { Spangenberg and Omann [84], Baines and Morgan [143] }\end{array}$ \\
\hline Decline of poverty & Vavik and Keitsch [1], Vallance, Perkins and Dixon [104] \\
\hline Social infrastructure & Cuthill [82], Chan and Lee [154] \\
\hline Social capital & $\begin{array}{l}\text { Cuthill [82], Lehtonen [2], Magis [155], Messer and Kecskes [156], } \\
\text { Semenza [157], Baines and Morgan [144], Dempsey et al. [94], Vavik and } \\
\text { Keitsch [1], Rogers, Gardner and Carlson [158], El-Husseiny and } \\
\text { Kesseiba [159], Bramley and Power [153], Rocak, Hospers and } \\
\text { Reverda [160], Colantonio and Dixon [141] }\end{array}$ \\
\hline Behavioural changes & Vallance, Perkins and Dixon [104] \\
\hline $\begin{array}{l}\text { Preservation of socio-cultural } \\
\text { patterns and practices }\end{array}$ & $\begin{array}{l}\text { Vavik and Keitsch [1], Vallance, Perkins and Dixon [104], Davidson and } \\
\text { Wilson [152], Colantonio and Dixon [141] }\end{array}$ \\
\hline
\end{tabular}


Table 2. Cont.

\begin{tabular}{|c|c|}
\hline Themes of Social Sustainability & Authors \\
\hline $\begin{array}{l}\text { Participation (Including } \\
\text { stakeholder participation) }\end{array}$ & $\begin{array}{l}\text { Littig and Grießler [11], Boström [137], Giddings, Hopwood and } \\
\text { O'Brien [147], Spangenberg and Omann [84], Murphy [146], } \\
\text { Thin et al. [149], Baines and Morgan [143], U.O'Hara [161], } \\
\text { Bramley et al. [162], Dempsey et al. [94], Vavik and Keitsch [1], } \\
\text { Galuppo et al. [134], Funk [135], Lindgreen et al. [124], Labuschagne, } \\
\text { Brent and Erck [128], Brown, Dillard and Marshall [125], Colantonio and } \\
\text { Dixon [141], Partridge [3] }\end{array}$ \\
\hline Human dignity & Littig and Grießler [11], Larsen [107], Vavik and Keitsch [1] \\
\hline Safety and security & $\begin{array}{l}\text { Thin et al. [149], Bramley et al. [162], Dempsey et al. [94], Vavik and } \\
\text { Keitsch [1], Glasson and Wood [103], Gauthier [139], Geibler et al. [110], } \\
\text { Tanzil and Beloff, [140] }\end{array}$ \\
\hline Sense of place and belonging & $\begin{array}{l}\text { Bramley et al. [162], Dempsey et al. [94], Glasson and Wood [103], } \\
\text { Bramley and Power [153], Colantonio and Dixon [141], Yung, Chan and } \\
\text { Xu [163], Yung and Chan [164] }\end{array}$ \\
\hline Education and training & $\begin{array}{l}\text { Spangenberg and Omann [84], Dempsey et al. [94], Colantonio and } \\
\text { Dixon [141] }\end{array}$ \\
\hline Employment & Sachs [98], Spangenberg and Omann [84], Dempsey et al. [94] \\
\hline $\begin{array}{l}\text { Community involvement and } \\
\text { development, community resilience }\end{array}$ & $\begin{array}{l}\text { Bramley et al. [162], Woodcraft, Hackett, and Caistor-arendar [165], } \\
\text { Castillo et al. [138], Bramley and Power [153], Colantonio [102], } \\
\text { Landorf [95], Magis [155], U. O'Hara [161] }\end{array}$ \\
\hline Fair operating practices & Bebbington and Dillard [113] \\
\hline Capacity for learning & Larsen [107] \\
\hline $\begin{array}{l}\text { No structural obstacles (to health, } \\
\text { influence, competence, impartiality } \\
\text { and meaning-making) }\end{array}$ & Missimer, Robert and Broman [116] \\
\hline
\end{tabular}

3.3. Establishing a Connection between Social Sustainability and Frugal Innovation: Practical Cases of Frugal Innovation and Their Links to the Social Sustainability Themes and SDGs

Social sustainability takes place when the work within a society and the related institutional arrangements satisfy an extended set of human needs [11]. Therefore, satisfying human needs is the priority of every socially sustainable society where the human well-being forms the foundation of every effort undertaken by society. Frugal innovation is a process whereby the needs of the citizens in the society are put first in order to solve some pressing societal problems. This section consists of practical examples of frugal innovations and shows the connections between frugal innovations and various themes of social sustainability. The researcher tries to illustrate with examples the link that each frugal innovation has with social sustainability and how each frugal innovation promotes the uptake of certain SDG. What emerges from each practical example of frugal innovation is the view that shows the societal benefits of frugal innovations and how such innovations tackle the big concept of social sustainability in their own little ways. Through this connection, the researcher is not trying to show that all the issues of social sustainability will be resolved by frugal innovations, but the purpose is to demonstrate the positive societal effects these frugal innovations have on a society and their potential to fulfill some pressing societal needs.

Following are some practical examples of frugal innovations. This section expands our understanding of the frugal innovations by showing their connections to social sustainability themes and SDGs.

\subsubsection{Aravind Eye Care}

Aravind Eye Hospital began as a modest hospital with 11 beds and four medical officers; it was created by Dr Venkataswamy in 1976 in India after his retirement, with the mission of eradicating needless blindness. Today, it is one of the largest facilities in the world for eye care and has grown into a network of eye hospitals, which have treated a total of nearly thirty-two million patients and performed nearly four million eye surgeries, the majority of which were inexpensive or free [42]. 
The Aravind Eye Care System now serves as a model for India and the rest of the world. From the beginning, a policy was put into place-some patients would pay while others received free care. Frugally innovative methods were employed to improve efficiency and help doctors save valuable time between surgeries such as that nurses prepare the next patient while the doctor is operating on a different one; the doctor moves directly from one patient to the next. Each doctor at Aravind performs about 2600 surgeries per year. These measures have pushed down the average cost of surgery [166]. The high level of quality at Aravind attracts patients from all over the world who are willing to pay the market price for their treatment and surgeries. The profit generated from these patients is then used to cross-subsidize and fund free surgeries for poor patients. At Aravind, every patient who can pay covers the costs of two who cannot. Because of high patient numbers, the revenue from paying patients not only covers costs for Aravind's free services but also generates a surplus that funds growth and expansion. Aravind pays for all its expansion projects from its profits, even though two-thirds of its patients receive free or subsidized care [31].

Aravind started an intraocular lens production facility, Aurolab, in 1992. In the 1990s, there were no lens manufacturers in India. With lenses costing \$200, they were not affordable for people in most developing countries. Aurolab devised efficient methods for creating lenses as per international standards. Today, Aurolab provides lenses at the low price of just $\$ 2$ each and also produces a wide range of ophthalmic products, exporting them to 130 countries around the world [166]. Frugal techniques also dramatically increased the number of cataract surgeries at Aravind and made it possible to deliver high quality eye care, even to the poorest people.

Table 3 illustrates how Aravind Eye Care, a practical example of frugal innovation, promotes social sustainability by addressing its different themes.

Table 3. Promotion of social sustainability through frugal innovations (Example: Aravind Eye Care).

\begin{tabular}{|c|c|c|}
\hline $\begin{array}{l}\text { Themes of Social } \\
\text { Sustainability }\end{array}$ & $\begin{array}{l}\text { Promotion of Social Sustainability through Frugal } \\
\text { Innovations (Aravind Eye Care) }\end{array}$ & Promotion of SDGs \\
\hline $\begin{array}{l}\text { Human health and } \\
\text { well-being/well-being } \\
\text { of generations }\end{array}$ & $\begin{array}{l}\text { The eyesight of } 45 \text { million people worldwide has been } \\
\text { snatched away, often needlessly [42]. Eradication of needless } \\
\text { blindness contributes to human well-being. }\end{array}$ & \multirow{4}{*}{$\begin{array}{l}\text { SDG 3: Aravind Eye Care } \\
\text { ensures healthy lives and } \\
\text { promotes well-being by } \\
\text { providing eyesight to millions } \\
\text { of people. } \\
\text { SDG 8: Aravind Eye Care } \\
\text { promotes sustained inclusive } \\
\text { and sustainable economic } \\
\text { growth and provides } \\
\text { productive employment to } \\
\text { numerous people. }\end{array}$} \\
\hline $\begin{array}{l}\text { Basic needs and } \\
\text { quality of life }\end{array}$ & $\begin{array}{l}\text { By empowering the blind people with the precious gift of } \\
\text { eyesight, their quality of life improves. }\end{array}$ & \\
\hline Social coherence & $\begin{array}{l}\text { By seeking out and catering to the poor blind population and } \\
\text { providing them with free treatment, social coherence is } \\
\text { being achieved. }\end{array}$ & \\
\hline $\begin{array}{l}\text { Social justice } \\
\text { and equity }\end{array}$ & $\begin{array}{l}\text { Both rich and poor receive this treatment. Poor patients who } \\
\text { would otherwise spend their lives in blindness receive the } \\
\text { wondrous gift of eyesight free of cost. }\end{array}$ & \\
\hline Social inclusion & $\begin{array}{l}\text { By empowering poor and marginalized people with eyesight, } \\
\text { Aravind Eye Care eradicates needless blindness thereby } \\
\text { promoting social inclusion. }\end{array}$ & \multirow{2}{*}{$\begin{array}{l}\text { SDG 9: Aravind Eye Care has } \\
\text { built a resilient infrastructure. } \\
\text { It promotes inclusive and } \\
\text { sustainable eye care and } \\
\text { fosters innovation. }\end{array}$} \\
\hline Decline of poverty & $\begin{array}{l}\text { Poor people regain their sight and receive another opportunity } \\
\text { to earn a living. }\end{array}$ & \\
\hline Social infrastructure & $\begin{array}{l}\text { Aravind Eye Hospital accommodates social services thereby } \\
\text { making it an excellent example of social infrastructure. }\end{array}$ & \multirow{2}{*}{$\begin{array}{l}\text { SDG 10: Aravind Eye Care } \\
\text { reduces inequality within the } \\
\text { country by empowering blind } \\
\text { people with the gift of eye sight. }\end{array}$} \\
\hline Social capital & $\begin{array}{l}\text { Community accountability and participation, which are } \\
\text { distinct indicators of social capital, are clearly evident. }\end{array}$ & \\
\hline Participation & $\begin{array}{l}\text { Marginalized people are given a second chance at becoming } \\
\text { contributing members of society. }\end{array}$ & \multirow{3}{*}{$\begin{array}{l}\text { SDG 12: By employing } \\
\text { sustainable Aravind Eye Care } \\
\text { model, each doctor at Aravind } \\
\text { Eye Care performs about } \\
2600 \text { surgeries per year. }\end{array}$} \\
\hline Human dignity & People regain their sight and are able to live a productive life. & \\
\hline Employment & $\begin{array}{l}\text { Aravind Eye Care caters to the problem of unemployment by } \\
\text { employing numerous people in India. }\end{array}$ & \\
\hline $\begin{array}{l}\text { Education and } \\
\text { training }\end{array}$ & $\begin{array}{l}\text { Aravind Eye Care collaborates with the World Health } \\
\text { Organization to design and offer structured training } \\
\text { programmes to eye care professionals at all levels. }\end{array}$ & $\begin{array}{l}\text { SDG 16: Aravind Eye Care has } \\
\text { emerged as a highly effective } \\
\text { and inclusive institution, which } \\
\text { promotes social inclusion. }\end{array}$ \\
\hline
\end{tabular}




\subsubsection{Jaipur Foot}

One of the best known examples of frugal innovation is Jaipur Foot. It is a prosthetic foot tailored specifically for the poor who otherwise have no access to expensive prosthetics. In the world today, there are approximately 25 million amputees, with that figure growing by approximately 250,000 each year [42]. For the poorest of the poor people in the developing world, losing a limb is devastating; it could impact their ability to provide livelihood for themselves and their families. The original Jaipur Foot was developed in 1968 by Ram Chandra, a sculptor in Jaipur, India. He was frustrated with the lack of an affordable supply of prosthetic limbs. Costing up to $\$ 12,000$, existing models were completely unobtainable for the majority of the Indian population [12]. Using rubber, wood and tire cord, he designed and manufactured a prosthetic foot for under $\$ 45$ that had great functionality. Today, over 20,000 individuals each year receive a free Jaipur Foot in India. This is an example of a frugal innovation that has the potential to empower the poor and marginalized people by allowing them to participate in the society, despite their limitations. Table 4 illustrates how Jaipur Foot, a practical example of frugal innovation, promotes social sustainability by addressing its different themes.

Table 4. Promotion of social sustainability through frugal innovations (Example: Jaipur Foot).

\begin{tabular}{|c|c|c|}
\hline $\begin{array}{l}\text { Themes of Social } \\
\text { Sustainability }\end{array}$ & $\begin{array}{l}\text { Promotion of Social Sustainability through Frugal } \\
\text { Innovations (Example: Jaipur Foot) }\end{array}$ & Promotion of SDGs \\
\hline $\begin{array}{l}\text { Human health and } \\
\text { well-being/well-being } \\
\text { of generations }\end{array}$ & $\begin{array}{l}\text { Empowering the poor by allowing them to take control } \\
\text { of their lives. }\end{array}$ & \multirow{5}{*}{$\begin{array}{l}\text { SDG 3: Jaipur Foot } \\
\text { ensures healthy lives and } \\
\text { promotes well-being by } \\
\text { serving amputees. }\end{array}$} \\
\hline $\begin{array}{l}\text { Basic needs and } \\
\text { quality of life }\end{array}$ & $\begin{array}{l}\text { Amputees who receive Jaipur Foot have a better } \\
\text { quality life. }\end{array}$ & \\
\hline Social coherence & Promotes solidarity by helping poor sections of society. & \\
\hline $\begin{array}{l}\text { Social justice } \\
\text { and equity }\end{array}$ & $\begin{array}{l}\text { Rich and poor alike receive this treatment. Poor people, } \\
\text { who have no means to afford expensive prosthetics, can } \\
\text { still receive the Jaipur Foot free of charge. }\end{array}$ & \\
\hline Social inclusion & $\begin{array}{l}\text { Social inclusion is about closing the distance that } \\
\text { separates people; this frugal innovation does just that by } \\
\text { allowing the amputees to live a more productive life. }\end{array}$ & \\
\hline Decline of poverty & $\begin{array}{l}\text { People have better employment prospects to therefore } \\
\text { support their families. }\end{array}$ & \multirow{4}{*}{$\begin{array}{l}\text { SDG 10: The Jaipur Foot } \\
\text { reduces inequality within } \\
\text { the country by } \\
\text { empowering amputees } \\
\text { with a prosthetic foot and } \\
\text { allowing them to lead } \\
\text { a more productive life. }\end{array}$} \\
\hline Social infrastructure & $\begin{array}{l}\text { The organization offering Jaipur Foot to the disabled, } \\
\text { Bhagwan Mahaveer Viklang Sahayata Samiti (BMVSS) is } \\
\text { the world's largest organisation serving the disabled and } \\
\text { a great example of a social infrastructure. }\end{array}$ & \\
\hline Participation & $\begin{array}{l}\text { Poor people who lose their limbs become unable to } \\
\text { provide for themselves and their families; however, with } \\
\text { the help of the Jaipur Foot, they are able to participate in } \\
\text { society, despite their limitations. }\end{array}$ & \\
\hline Human dignity & $\begin{array}{l}\text { It empowers people and helps them continue their lives } \\
\text { with dignity. }\end{array}$ & \\
\hline
\end{tabular}

\subsubsection{Kerala's Palliative Care}

Kerala's Neighbourhood Network in Palliative Care is a system for social care delivered in Kerala, India whereby volunteers from the local community are trained to identify the problems of the chronically ill in their areas and to intervene effectively [12]. The network looks after more than 6000 patients at any given time and all their services are free. More than 5000 community volunteers offer their services without any remuneration. Tens of doctors and nurses who provide expert support are employed by the community. All the resources needed for medicines, food or support for children and salaries are raised from local community donations [167]. 
Kerala's palliative care is an excellent example of frugal innovation that promotes social sustainability. This network recognizes the importance of social relationships, feels compassion towards old, sick and needy patients in their society and delivers help selflessly in order to make their society a better place.

Table 5 illustrates how Kerala's Palliative Care, a practical example of frugal innovation promotes social sustainability by addressing its different themes.

Table 5. Promotion of social sustainability through frugal innovations (Example: Kerala's Palliative Care).

\begin{tabular}{|c|c|c|}
\hline $\begin{array}{l}\text { Themes of Social } \\
\text { Sustainability }\end{array}$ & $\begin{array}{l}\text { Promotion of Social Sustainability through Frugal } \\
\text { Innovations (Example: Kerala's Palliative Care) }\end{array}$ & Promotion of SDGs \\
\hline $\begin{array}{l}\text { Human health and } \\
\text { well-being/well-being } \\
\text { of generations }\end{array}$ & $\begin{array}{l}\text { Social care delivered to the chronically ill by volunteers } \\
\text { from the local community is an excellent example of } \\
\text { promoting human health and well-being. }\end{array}$ & \multirow{12}{*}{$\begin{array}{l}\text { SDG 3: Kerala's } \\
\text { Palliative Care promotes } \\
\text { the well-being of severely } \\
\text { sick people. }\end{array}$} \\
\hline $\begin{array}{l}\text { Basic needs and } \\
\text { quality of life }\end{array}$ & $\begin{array}{l}\text { Through Kerala's Palliative Care, quality of life of the } \\
\text { acutely sick people is improved. }\end{array}$ & \\
\hline Social coherence & $\begin{array}{l}\text { It is an excellent example of social coherence, where } \\
\text { importance of community is recognized. }\end{array}$ & \\
\hline $\begin{array}{l}\text { Social justice } \\
\text { and equity }\end{array}$ & $\begin{array}{l}\text { Through palliative care, access to basic services for } \\
\text { health and well-being to all sick people, irrespective of } \\
\text { their differences in status, religion or creed is possible. }\end{array}$ & \\
\hline Social inclusion & $\begin{array}{l}\text { It promotes inclusion at the level of individuals, groups } \\
\text { and society. }\end{array}$ & \\
\hline Social infrastructure & $\begin{array}{l}\text { Kerala's Palliative Care is an excellent example of } \\
\text { a social infrastructure delivered through communities. }\end{array}$ & \\
\hline Social capital & $\begin{array}{l}\text { It shows community accountability, responsibility, } \\
\text { compassion and social service. }\end{array}$ & \\
\hline $\begin{array}{l}\text { Behavioral/ } \\
\text { Attitude changes }\end{array}$ & $\begin{array}{l}\text { Thinking selflessly about the old and sick members of } \\
\text { the society and working towards the welfare of the } \\
\text { society is the attitude that all communities need. }\end{array}$ & \\
\hline $\begin{array}{l}\text { Preservation of } \\
\text { socio-cultural } \\
\text { patterns and practices }\end{array}$ & $\begin{array}{l}\text { This innovation preserves the socio-cultural practices of } \\
\text { old India, which urban India has forgotten over time. } \\
\text { Collectivism has been the essence of Indian culture. }\end{array}$ & \\
\hline Participation & $\begin{array}{l}\text { Approximately } 5000 \text { community volunteers participate } \\
\text { in community welfare without a salary and care for more } \\
\text { than } 6000 \text { patients. }\end{array}$ & \\
\hline Human dignity & $\begin{array}{l}\text { Palliative care aids chronically ill people and helps them } \\
\text { live the rest of their lives with hope. }\end{array}$ & \\
\hline $\begin{array}{l}\text { Community } \\
\text { involvement and } \\
\text { development }\end{array}$ & $\begin{array}{l}\text { It is an excellent example of how a community can get } \\
\text { involved to deliver social care. }\end{array}$ & \\
\hline
\end{tabular}

\subsubsection{Narayana Hrudayalaya}

The Narayana Hrudayalaya Group in India provides world-class cardiac care at radically low costs by applying the philosophies of mass production and lean manufacturing. Heart surgery through this group costs between $\$ 2000$ and $\$ 5000$, compared with $\$ 20,000-\$ 100,000$ in the US. Poor patients are operated on free of charge. At least 60 operations a week are provided to poor patients; yet, the group still manages to maintain a higher profit margin than the average American hospital. The success of the Narayana Hrudayalaya Group is a striking example of frugal innovation in India [12].

This example reflects how frugal innovations and techniques help solve societal problems. Frugal and innovative techniques have helped Narayana Hrudayalaya to not only deliver high quality cardiac care but also address societal needs by helping the poorest sections of society. Even though poor patients receive free treatment, this chain of hospitals maintains a high profit margin due to 
efficient and innovative techniques and strategies. Further, it also works towards human well-being and helps achieve social sustainability. Table 6 illustrates how Narayana Hrudayalaya, a practical example of frugal innovation, promotes social sustainability by addressing its different themes.

Table 6. Promotion of social sustainability through frugal innovations (Example: Narayana Hrudayalaya).

\begin{tabular}{|c|c|c|}
\hline $\begin{array}{l}\text { Themes of Social } \\
\text { Sustainability }\end{array}$ & $\begin{array}{l}\text { Promotion of Social Sustainability through } \\
\text { Frugal Innovations (Narayana Hrudayalaya) }\end{array}$ & Promotion of SDGs \\
\hline $\begin{array}{l}\text { Human health and } \\
\text { well-being/well-being } \\
\text { of generations }\end{array}$ & $\begin{array}{l}\text { Offering world class cardiac care at radically low } \\
\text { cost promotes human well-being by all means. }\end{array}$ & \multirow{5}{*}{$\begin{array}{l}\text { SDG 3: Narayana Hrudayalaya } \\
\text { ensures healthy lives and } \\
\text { promotes well-being. } \\
\text { SDG 8: Narayana Hrudayalaya } \\
\text { promotes sustained inclusive and } \\
\text { sustainable economic growth, and } \\
\text { provides productive employment } \\
\text { to numerous people. } \\
\text { SDG 9: Narayana Hrudayalaya } \\
\text { has built resilient infrastructure, } \\
\text { promoted inclusive and } \\
\text { sustainable world class cardiac } \\
\text { care at radically low cost and has } \\
\text { employed a highly innovative } \\
\text { healthcare model. }\end{array}$} \\
\hline $\begin{array}{l}\text { Basic needs and } \\
\text { quality of life }\end{array}$ & $\begin{array}{l}\text { By allowing access to the best healthcare, even to } \\
\text { those who otherwise cannot afford it, Narayana } \\
\text { Hrudayalaya improves quality of life. }\end{array}$ & \\
\hline Social coherence & $\begin{array}{l}\text { Offering free cardiac care to thousands of } \\
\text { patients, social coherence is being achieved. }\end{array}$ & \\
\hline $\begin{array}{l}\text { Social justice } \\
\text { and equity }\end{array}$ & $\begin{array}{l}\text { Both rich and poor receive this treatment. Poor } \\
\text { patients who otherwise cannot dream of highly } \\
\text { expensive surgeries, such as those performed in } \\
\text { the US, receive it free of charge in India. }\end{array}$ & \\
\hline Social inclusion & $\begin{array}{l}\text { By curing poor and marginalized people, } \\
\text { Narayana Hrudayalaya promotes } \\
\text { social inclusion. }\end{array}$ & \\
\hline Decline of poverty & $\begin{array}{l}\text { Poor people regain their health and get an } \\
\text { opportunity to earn a living again. }\end{array}$ & \multirow{2}{*}{$\begin{array}{l}\text { SDG 10: Narayana Hrudayalaya } \\
\text { reduces inequality within the } \\
\text { country by operating people free } \\
\text { of cost. }\end{array}$} \\
\hline & $\begin{array}{l}\text { Narayana Hrudayalaya accommodates social } \\
\text { services thereby making it an excellent example }\end{array}$ & \\
\hline & & \multirow{3}{*}{$\begin{array}{l}\text { SDG 12: Narayana Hrudayalaya } \\
\text { represents an excellent case of } \\
\text { sustainable production and } \\
\text { consumption; it drastically lowers } \\
\text { heart surgery costs through } \\
\text { employing the principles of mass } \\
\text { production and lean } \\
\text { manufacturing. }\end{array}$} \\
\hline Social capital & $\begin{array}{l}\text { Community accountability and participation } \\
\text { which are distinct indicators of social capital are } \\
\text { clearly evident. }\end{array}$ & \\
\hline Participation & $\begin{array}{l}\text { By providing a micro-insurance scheme that } \\
\text { allows poor people to access quality healthcare } \\
\text { at INR } 5 \text { ( } 11 \text { cents) per month, Narayana } \\
\text { Hrudayalaya promotes participation. }\end{array}$ & \\
\hline Human dignity & $\begin{array}{l}\text { Poor people get a chance to live their lives } \\
\text { with dignity. }\end{array}$ & \multirow{2}{*}{$\begin{array}{l}\text { SDG 16: Narayana Hrudayalaya } \\
\text { has emerged as a highly effective } \\
\text { and inclusive institution that } \\
\text { promotes social inclusion. }\end{array}$} \\
\hline Employment & $\begin{array}{l}\text { Narayana Hrudayalaya provides employment } \\
\text { to numerous people. }\end{array}$ & \\
\hline
\end{tabular}

\subsubsection{Vortex Engineering (Solar Powered ATMs)}

Vortex Engineering Private Limited is an innovative Indian company that develops and manufactures Automated Teller Machines (ATMs), which are "highly reliable, rugged, easy to use and eco-friendly" [168]. Their ATMs are specially designed to suit the challenging environment prevalent in rural and semi-urban areas, e.g., unreliable power supply and higher illiteracy levels of end-users [29]. To overcome unreliable power supplies prevalent in rural areas, Vortex Engineering designed and built an ATM with a solar panel that consumes approximately $10 \%$ of the total energy requirement of a conventional ATM [168]. The solar model generates less heat and thus eliminates the need for continuous air conditioning [12]; it can cope with temperatures ranging between $0{ }^{\circ} \mathrm{C}$ and $50{ }^{\circ} \mathrm{C}$ [29]. Vortex ATMs also have a built-in fingerprint identification system, a feature that works well for the uneducated rural masses, which eliminates the need for a personal identification number (PIN). The total cost of ownership for Vortex machines comes to $50 \%$ less than that of conventional ATMs [29]. Table 7 illustrates how solar powered ATMs from Vortex Engineering promote social sustainability by addressing its different themes. 
Table 7. Promotion of social sustainability through frugal innovations (Example: Vortex Engineering ATMs).

\begin{tabular}{lll}
\hline $\begin{array}{l}\text { Themes of Social } \\
\text { Sustainability }\end{array}$ & $\begin{array}{l}\text { Promotion of Social Sustainability through } \\
\text { Frugal Innovations (Vortex Engineering ATMs) }\end{array}$ & Promotion of SDGs \\
\cline { 1 - 2 } Social inclusion & $\begin{array}{l}\text { It promotes social inclusion by providing the BOP } \\
\text { population with easy access to ATM technology. }\end{array}$ & $\begin{array}{l}\text { SDG 9: Vortex Engineering is considered } \\
\text { a highly innovative company, which designs } \\
\text { highly reliable and eco-friendly technology. }\end{array}$ \\
$\begin{array}{lll}\text { Social justice } \\
\text { and equity }\end{array}$ & $\begin{array}{l}\text { It provides poor people with an opportunity to } \\
\text { use technology. }\end{array}$ & $\begin{array}{l}\text { SDG 10: It gives poor people an opportunity to } \\
\text { use ATMs, even if they are illiterate. }\end{array}$ \\
$\begin{array}{lll}\text { Basic needs and } \\
\text { quality of life }\end{array}$ & The quality of life of rural population improves. & $\begin{array}{l}\text { SDG 12: Solar powered ATMs are the most } \\
\text { sustainable ATMs made; they consume } \\
\text { approximately } 10 \% \text { of the total energy of } \\
\text { a conventional ATM and reduce } \mathrm{CO}_{2} \text { emissions } \\
\text { by at least 18,500 kg per annum [29]. }\end{array}$ \\
\cline { 1 - 2 } Capacity for learning & $\begin{array}{l}\text { Provides illiterate people a chance to learn to } \\
\text { operate previously unfamiliar technology and } \\
\text { build new skills. }\end{array}$ & \\
\hline
\end{tabular}

\subsubsection{SELCO}

SELCO Solar Private Limited is a social enterprise in India that works to bring solar power to underserved businesses and households. This company is making solar power a feasible option for the rural population. Its business model is highly innovative, whereby solar power is sold as a service to the poor customers, and micro-loans for these low-income customers are arranged by SELCO itself through the local banks or microfinance organizations, with SELCO acting as a guarantor [169]. SELCO's model allows the full costs of solar power to be covered over time [12]. Thus far, SELCO has sold over 200,000 solar systems in India [169]. Table 8 illustrates how SELCO, a practical example of frugal innovation promotes social sustainability by addressing its different themes.

Table 8. Promotion of social sustainability through frugal innovations (Example: SELCO).

\begin{tabular}{|c|c|c|}
\hline $\begin{array}{l}\text { Themes of Social } \\
\text { Sustainability }\end{array}$ & $\begin{array}{l}\text { Promotion of Social Sustainability } \\
\text { through Frugal Innovations (SELCO) }\end{array}$ & Promotion of SDGs \\
\hline $\begin{array}{l}\text { Human health and } \\
\text { well-being/well-being } \\
\text { of generations }\end{array}$ & $\begin{array}{l}\text { Less dependency on conventional } \\
\text { non-renewable energy resources has } \\
\text { a positive effect on the health and } \\
\text { well-being of people. }\end{array}$ & \multirow{4}{*}{$\begin{array}{l}\text { SDG 3: SELCO ensures good health and } \\
\text { well-being by enabling people to use clean } \\
\text { energy instead of traditional fossil fuels. } \\
\text { SDG 4: Due to uninterrupted power supply, } \\
\text { poor students have an increased opportunity } \\
\text { to spend more hours studying in the evenings. } \\
\text { SDG 7: Solar power is a renewable, } \\
\text { non-polluting energy resource. In the absence } \\
\text { of such an inclusive business model, it would } \\
\text { not have been possible to involve the BOP } \\
\text { population as consumers. }\end{array}$} \\
\hline \multirow{2}{*}{$\begin{array}{l}\text { Basic needs and } \\
\text { quality of life }\end{array}$} & \multirow{2}{*}{$\begin{array}{l}44 \% \text { of the Indian population lack } \\
\text { electricity. SELCO has provided reliable } \\
\text { electricity to millions who otherwise had } \\
\text { no or limited access to electricity. This has } \\
\text { resulted in a better quality of life. Further, } \\
\text { working for longer hours has a positive } \\
\text { impact on the income level of } \\
\text { BOP population. }\end{array}$} & \\
\hline & & \\
\hline \multirow{2}{*}{$\begin{array}{l}\text { Social justice } \\
\text { and equity }\end{array}$} & \multirow{2}{*}{$\begin{array}{l}\text { Provided an opportunity to BOP } \\
\text { population to become } \\
\text { respected customers. }\end{array}$} & \\
\hline & & \multirow{2}{*}{$\begin{array}{l}\text { SDG 8: SELCO has promoted sustained, } \\
\text { inclusive and sustainable economic growth } \\
\text { and provided employment to many. }\end{array}$} \\
\hline \multirow[b]{2}{*}{ Social inclusion } & \multirow[b]{2}{*}{$\begin{array}{l}\text { Enabled the poorest segments of the } \\
\text { population to buy solar electric systems } \\
\text { through an innovative business model. } \\
\text { Electricity enables them to work for } \\
\text { longer hours, which was } \\
\text { previously impossible. }\end{array}$} & \\
\hline & & $\begin{array}{l}\text { SDG 9: SELCO'S innovative potential and } \\
\text { inclusive business model have been } \\
\text { appreciated worldwide. This is evident from } \\
\text { the fact that the founder of SELCO received } \\
\text { the 'Asian. }\end{array}$ \\
\hline Behavioral changes & $\begin{array}{l}\text { Shifting to green energy has resulted in } \\
\text { promotion of ecofriendly behavior. }\end{array}$ & \multirow{2}{*}{$\begin{array}{l}\text { Nobel Prize' in } 2011 \text { as well as the Ashden } \\
\text { Award and the Outstanding Achievement } \\
\text { Award }[12,170] .\end{array}$} \\
\hline \multirow{2}{*}{$\begin{array}{l}\text { Education } \\
\text { and training }\end{array}$} & \multirow{2}{*}{$\begin{array}{l}\text { Poor students who had no or limited } \\
\text { access to electricity in the evenings can } \\
\text { now study longer. }\end{array}$} & \\
\hline & & \multirow{2}{*}{$\begin{array}{l}\text { SDG 10: SELCO has been successful in } \\
\text { reducing inequality in society by enabling } \\
\text { poor customers to build links to financial } \\
\text { institutions and enabling them to use solar } \\
\text { electric systems. }\end{array}$} \\
\hline Employment & $\begin{array}{l}\text { SELCO has not only provided } \\
\text { employment to its own employees but } \\
\text { also to many rural entrepreneurs who } \\
\text { rent out solar lights to vendors } \\
\text { and institutions. }\end{array}$ & \\
\hline
\end{tabular}




\subsubsection{M-Pesa}

M-Pesa is a mobile phone-based money transfer service, launched in 2007 by Vodafone for Safaricom and Vodacom in Kenya and Tanzania. Since its launch in 2007, M-Pesa has expanded to other countries like Afghanistan, South Africa, India, Romania and Albania. M-Pesa allows users to deposit, withdraw, transfer money and pay for goods and services easily with a mobile device [171]. The service enables its users to deposit money into an account stored on their cell phones, withdraw or transfer money to other users and non-users, pay bills and purchase airtime. Users are charged a small fee for sending and withdrawing money using the service. It is a branchless banking service whereby the M-Pesa users can deposit and withdraw money from a network of agents like airtime resellers and retail outlets [171].

M-Pesa has become the most successful mobile financial service in the developing world. This service has given access to the financial system to millions of people and it has been recognized for reducing crime in an otherwise largely cash-based society [172]. Table 9 illustrates how M-Pesa, a practical example of frugal innovation, promotes social sustainability by addressing its different themes.

Table 9. Promotion of social sustainability through frugal innovations (Example: M-Pesa).

\begin{tabular}{|c|c|c|}
\hline $\begin{array}{l}\text { Themes of Social } \\
\text { Sustainability }\end{array}$ & $\begin{array}{l}\text { Promotion of Social Sustainability through } \\
\text { Frugal Innovations (M-Pesa) }\end{array}$ & Promotion of SDGs \\
\hline Basic needs and quality of life & $\begin{array}{l}\text { M-Pesa has improved the quality of life of } \\
\text { millions of BOP customers by empowering } \\
\text { them with branchless banking service. }\end{array}$ & $\begin{array}{l}\text { SDG 1: M-Pesa has reduced } \\
\text { poverty in the regions of its } \\
\text { operation. }\end{array}$ \\
\hline Social justice and equity & $\begin{array}{l}\text { It provides an opportunity to millions of poor } \\
\text { people to become respected customers. }\end{array}$ & \multirow{2}{*}{$\begin{array}{l}\text { SDG 3: M-Pesa has been involved } \\
\text { with Bridge International } \\
\text { Academy which provides } \\
\text { education to poorest areas of } \\
\text { Kenya at a very low cost ( } \$ 4 \text { in } \\
\text { monthly tuition per student). }\end{array}$} \\
\hline Social inclusion & $\begin{array}{l}\text { It promotes social inclusion by providing the } \\
\text { poor population with an access to financial } \\
\text { services that they were otherwise devoid of. }\end{array}$ & \\
\hline Decline of poverty & $\begin{array}{l}\text { M-Pesa program has transferred more than US } \\
\$ 1.4 \text { trillion in electronic funds and significantly } \\
\text { contributed to poverty alleviation [173]. }\end{array}$ & $\begin{array}{l}\text { SDG 8: M-Pesa has promoted } \\
\text { sustained, inclusive and } \\
\text { sustainable economic growth. }\end{array}$ \\
\hline Capacity for learning & $\begin{array}{l}\text { It provides people with an opportunity to } \\
\text { operate mobile phone technology and build } \\
\text { new skills. }\end{array}$ & \multirow{2}{*}{$\begin{array}{l}\text { SDG 9: M-Pesa is a highly } \\
\text { innovative solution, which has } \\
\text { dramatically improved the lives of } \\
\text { millions of people. }\end{array}$} \\
\hline & $\begin{array}{l}\text { Research has indicated that services like M-Pesa } \\
\text { might play a significant role in anti-money }\end{array}$ & \\
\hline Safety and security & $\begin{array}{l}\text { laundering and counter-terrorist financing } \\
\text { efforts [173]. It is also a safe alternative to } \\
\text { travelling with large amounts of cash. }\end{array}$ & \multirow{2}{*}{$\begin{array}{l}\text { SDG 10: M-Pesa has succeeded in } \\
\text { reducing inequality in society by } \\
\text { enabling BOP customers to build } \\
\text { links to financial services. }\end{array}$} \\
\hline Human dignity & $\begin{array}{l}\text { This service has improved the lives of millions } \\
\text { of Kenyans. }\end{array}$ & \\
\hline $\begin{array}{l}\text { Participation (Including } \\
\text { stakeholder participation) }\end{array}$ & $\begin{array}{l}\text { Since the launch of M-Pesa in 2007, over } \\
15 \text { million users have been using the } \\
\text { service [173]. }\end{array}$ & $\begin{array}{l}\text { SDG 12: M-Pesa is an excellent } \\
\text { case of sustainable mobile phone } \\
\text { based financial service. }\end{array}$ \\
\hline
\end{tabular}

\subsubsection{Craftskills East Africa limited}

Craftskills East Africa limited is a social enterprise in Kenya that sells renewable energy equipment to farms, village collectives and small businesses in East Africa. It builds wind power generation devices from local materials to supply energy to small, dispersed off-grid African villages [174,175]. The local materials include old motorcycle engines, which are essential components of wind turbines. Craftskills' wind turbine is an excellent example of an affordable and resource-scarce solution that serves the customers of Kenya with a reliable and easy-to-use product at a low price [176]. Craftskills has been successful in supplying equipment that in some cases light the whole village and, in other cases, the electricity generated is used for water pumps that supply irrigation and clean 
drinking water [174]. Craftskills East Africa limited solves the pressing problem of lack of electricity in Kenya by making cheap yet efficient wind turbines for the Kenyan people and supplies affordable clean energy to them. Table 10 illustrates how Craftskills East Africa limited, a practical example of frugal innovation, promotes social sustainability by addressing its different themes.

Table 10. Promotion of social sustainability through frugal innovations (Example: Craftskills East Africa limited).

\begin{tabular}{|c|c|c|}
\hline $\begin{array}{l}\text { Themes of Social } \\
\text { Sustainability }\end{array}$ & $\begin{array}{l}\text { Promotion of Social Sustainability through } \\
\text { Frugal Innovations (Craftskills East } \\
\text { Africa Limited) }\end{array}$ & Promotion of SDGs \\
\hline $\begin{array}{l}\text { Human health and } \\
\text { well-being/well-being } \\
\text { of generations }\end{array}$ & $\begin{array}{l}\text { Use of wind power has positive health benefits } \\
\text { compared to non-renewable energy resources. }\end{array}$ & \multirow{3}{*}{$\begin{array}{l}\text { SDG 3: Craftskills ensures good } \\
\text { health and well-being by enabling } \\
\text { people to use clean wind energy } \\
\text { instead of traditional fossil fuels. } \\
\text { SDG 7: Wind power is } \\
\text { a renewable, non-polluting energy } \\
\text { resource. Craftskills ensures access } \\
\text { to affordable, reliable and clean } \\
\text { energy to Kenyan people. }\end{array}$} \\
\hline $\begin{array}{l}\text { Basic needs and } \\
\text { quality of life }\end{array}$ & $\begin{array}{l}\text { Craftskills has provided clean electricity to } \\
\text { people who otherwise had no or limited access } \\
\text { to electricity. They have also supported farms } \\
\text { by selling them electricity equipment for water } \\
\text { pumps used for agricultural purposes. }\end{array}$ & \\
\hline $\begin{array}{l}\text { Social justice } \\
\text { and equity }\end{array}$ & $\begin{array}{l}\text { It provides an opportunity to BOP population } \\
\text { to become respected customers. }\end{array}$ & \\
\hline Social inclusion & $\begin{array}{l}\text { Poor segments of population get an } \\
\text { opportunity to buy reliable wind turbines at } \\
\text { low costs and electrify their homes. }\end{array}$ & \multirow{4}{*}{$\begin{array}{l}\text { SDG 9: Craftskills' ability to } \\
\text { generate frugal innovation in } \\
\text { a resource constrained } \\
\text { environment and create more from } \\
\text { less is a step towards building } \\
\text { resilient infrastructure. } \\
\text { SDG 10: Craftskills has been } \\
\text { successful in reducing inequality } \\
\text { in society by providing poor } \\
\text { people an access to electricity. }\end{array}$} \\
\hline Poh & $\begin{array}{l}\text { In Africa, renewable energy is perceived as } \\
\text { second class [175]. Motivating people to use }\end{array}$ & \\
\hline benavioral cna & $\begin{array}{l}\text { electricity generated through green wind } \\
\text { energy turbines is a positive behavioural } \\
\text { change that promotes ecofriendly behaviour. }\end{array}$ & \\
\hline Human dignity & $\begin{array}{l}\text { Electrifying villages or supplying power to } \\
\text { schools, health facilities, market places or hotels } \\
\text { has changed the lives of people in BOP market } \\
\text { like Kenya. }\end{array}$ & \\
\hline
\end{tabular}

From the discussion above, it can be argued that frugal innovation can be considered as one practical step towards realizing social sustainability. Figure 3 shows the connection between frugal innovation and social sustainability through linking frugal innovation to the social sustainability themes. Every frugal innovation promotes various social sustainability themes.

For example, the social sustainability themes shown in Figure 3 can be seen as consequences of the frugal innovations, with some themes recurring in almost all the cases such as social inclusion, human well-being, quality of life, equity and so on. 


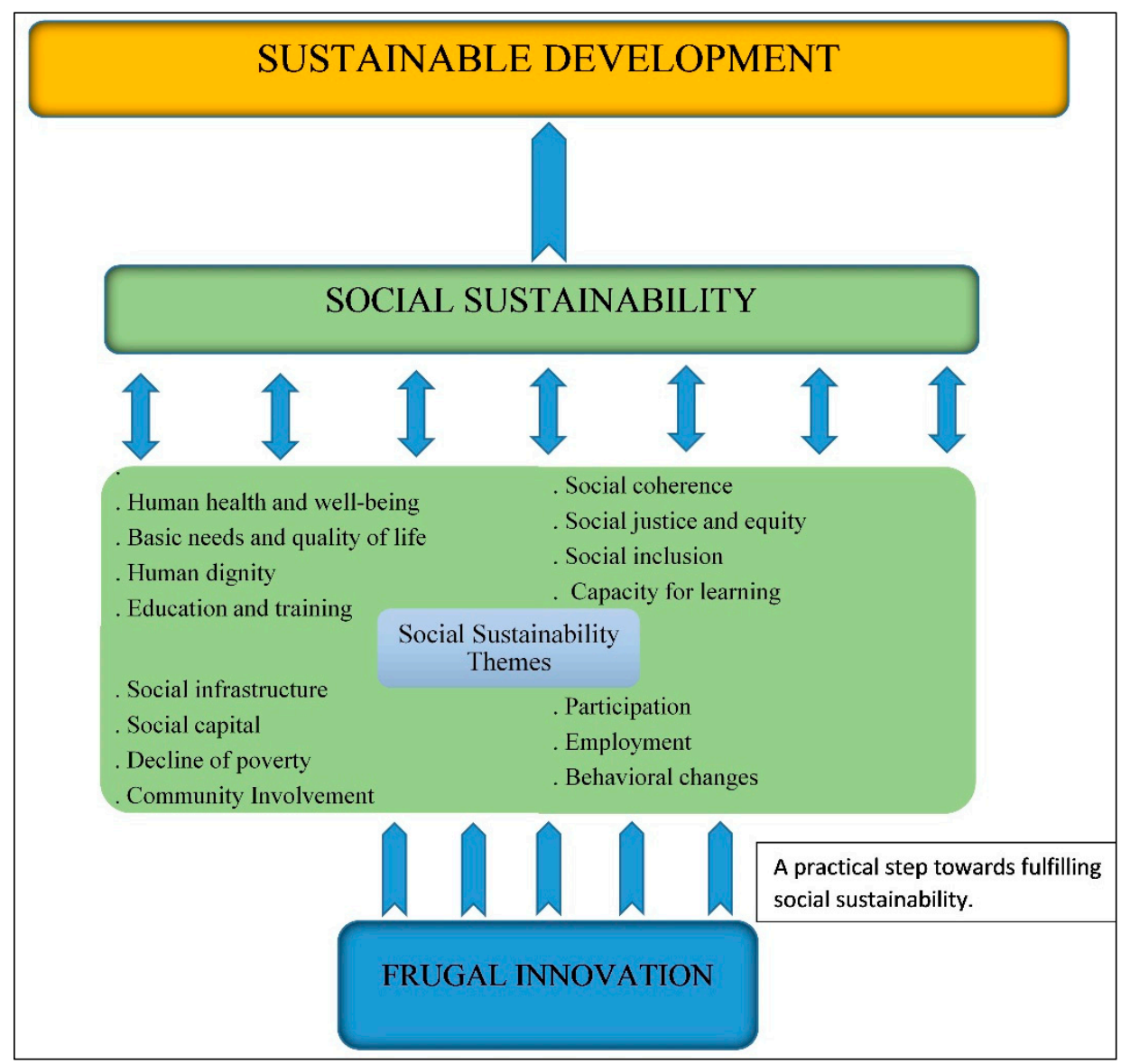

Figure 3. Connection between frugal innovation and social sustainability.

\section{Implications for Theory and Practice}

This study is an attempt to show a connection between frugal innovation and social sustainability. The researcher believes that frugal innovation and social sustainability are intertwined, and this study is one of the initial attempts at this integration. Eight cases of frugal innovation were analyzed in the light of social sustainability themes. Based on the findings drawn in relation to social sustainability, the implications of this study will be discussed.

In almost all the cases of frugal innovation, important themes of social sustainability are visible. Through these practical cases, it is seen that issues like human well-being, basic needs and quality of life, social justice, social inclusion, poverty reduction, learning capacity and many other social sustainability themes are being addressed. All the frugal innovation cases offer solutions to existing societal problems. Firstly, frugal innovation helps in closing the distances that separate people by promoting connectedness within and outside the community, which is one of the most important principles of social sustainability [100]. Frugal innovation is one way to solve the challenges of social inclusion in BOP markets. Secondly, human well-being is also an essential outcome of frugal innovations. In all the examples mentioned above, human well-being is being promoted. An interesting example is Neusoft, China's IT service provider which has developed telemedicine applications for millions of Chinese living in rural areas that deliver affordable healthcare to poor people [26]. Thirdly, in BOP markets, where there is unequitable distribution of resources, through some frugal innovations, even the poorest sections of society also gain access to essential services. Jaipur Foot, Aravind Eye care, Vortex ATMs, SELCO, M-Pesa and Narayana Hrudayalaya are examples of such frugal innovations. Equity ensures mechanisms that guarantee equitable sharing of society's benefits and costs [106]. Through frugal innovations, it has become possible to provide opportunities and access to the basic 
amenities for the poorest of the poor. Lastly, frugal innovations work towards the goal of social coherence, whereby members of a society play an active role in assisting marginalized communities. Social coherence is a measure of solidarity among the members of a society. Social sustainability of a society can be evaluated in terms of how well the society is involved in activities and how tolerant its members are towards, for instance, marginalized groups [11]. Through some frugal innovations, such as Kerala's Palliative Care, the goal of social coherence is achieved, and a feeling of passion towards helping community members is evident. Frugal innovation plays an important role in fulfilling social sustainability; it promotes SDGs and contributes towards the larger goal of sustainable development. The most common SDGs promoted by the frugal innovation cases presented above include SDGs 1, 3, $4,7,8,9,10,12$ and 16 . Therefore, it can be implied that application of frugal innovation in a society is a tiny step towards realizing sustainable development.

With regards to managerial practice, this research may be useful for frugal innovators who could benefit from this knowledge. Most often, frugal innovators innovate to solve a pressing societal need; if they become aware of this link between frugal innovation and social sustainability, they could perhaps market their products even better and show the impact of these products from a larger perspective. They can more easily evaluate the benefits of the connection between these concepts and use this information while promoting their frugal innovations.

\section{Conclusions}

The literature concerning social sustainability and frugal innovation was reviewed, and it was discovered that the two fields of study are connected. The essential themes of social sustainability were studied, and their relation to frugal innovation was explored. The results of this study are particularly novel in that frugal innovation has not been linked solely to social sustainability prior to this research. Social sustainability is one of the most important pillars of sustainable development and, through this paper, it is possible to realize social sustainability goals via the application of frugal innovation. The role of frugal innovation towards promoting SDGs concerning social sustainability is emphasized.

Socially sustainable societies provide equal access and opportunities to all members for both survival and the fulfilment of their development potential [147]. In the business context, MNCs have failed to give equal access to their products and services. They have innovated for the top of the pyramid customers, who can afford their innovations. However, thus far, they have ignored the BOP customers, treating them as unprofitable sections of the population [42]. In contrast, frugal innovators intentionally seek out opportunities with these underserved customers. Frugal innovators pull poor customers into the mainstream, innovate for them and provide affordable and viable solutions to their needs. Therefore, businesses that innovate frugally contribute towards societal goals alongside economic ones.

This article argues that social sustainability may be expanded to incorporate a stronger emphasis on practical ways to fulfil socially sustainable goals. For instance, practical contributions of frugal innovation towards solving certain pressing social needs have been explored in this paper. Many examples have been provided that show the exemplary contribution of such frugal innovations towards society while also showing connections between social sustainability and frugal innovation.

This study may have its limitations. The researcher did not have any access to better instruments to measure the social sustainability of frugal innovations. Therefore, the researcher was limited to deriving social sustainability themes and using SDGs as a basis for measuring social sustainability. It is certainly a little-researched field and therefore, a good follow-up study is recommended that can demonstrate a stronger relationship between the two researched concepts. Some frugal innovation case studies from different BOP countries and their links to social sustainability could be studied. This could enrich our understanding of these innovations and their links to positive societal transformation in different BOP markets. It would also be beneficial to study the role of socially driven businesses and innovations towards achieving social sustainability. Measuring the social sustainability of frugal 
innovations is challenging; hence, to enhance the understanding of this relationship, it is important to devise better indicators, which will make it possible to measure this relationship more accurately.

The multidisciplinary nature of social sustainability has made it possible to view this field through a different angle. The essential themes of social sustainability presented, along with the practical examples from frugal innovations, offer a different viewpoint on the connections between the two different fields.

Acknowledgments: I gratefully acknowledge the financial support received from the Finnish Cultural Foundation, Päijät-Häme Regional Fund and the Foundation for Economic Education. I want to thank Helinä Melkas and Satu Pekkarinen who provided useful comments on an earlier version of the paper. Their guidance and invaluable support is greatly appreciated. Lastly, I want to thank two anonymous reviewers for reviewing this paper.

Conflicts of Interest: The author declares no conflict of interest.

\section{References}

1. Vavik, T.; Keitsch, M. Exploring relationships between Universal Design and Social Sustainable Development: Some Methodological Aspects to the Debate on the Sciences of Sustainability. Sustain. Dev. 2010, 18, 295-305. [CrossRef]

2. Lehtonen, M. The environmental-social interface of sustainable development: Capabilities, social capital, institutions. Ecol. Econ. 2004, 49, 199-214. [CrossRef]

3. Partridge, E. Social sustainability: A useful theoretical framework? In Proceedings of the Australasian Political Science Association Annual Conference, Dunedin, New Zealand, 28-30 September 2005.

4. Torjman, S. The Social Dimension of Sustainable Development, a Paper Prepared for Commissioner of Environment and Sustainable Development; Caledon Institute of Social Policy: Ottawa, ON, Canada, 2000.

5. Tiwari, R.; Herstatt, C. India-A Lead Market for Frugal Innovations? Extending the Lead Market Theory to Emerging Economies; Working Paper No. 67; Institute for Technology and Innovation Management, Hamburg University of Technology: Hamburg, Germany, 2012.

6. DeSimone, L.D.; Popoff, F. Eco-Efficiency: The Business Link to Sustainable Development; MIT Press: Cambridge, MA, USA, 2000.

7. Porritt, J. Capitalism as if the World Matters; Earthscan: Sterling, VA, USA, 2005.

8. Ahlstrom, D. Innovation and Growth: How Business Contributes to Society. Acad. Manag. Perspect. 2010, 24, 11-24. [CrossRef]

9. Brem, A.; Ivens, B. Do Frugal and Reverse Innovation Foster Sustainability? Introduction of a Conceptual Framework. J. Technol. Manag. Grow. Econ. 2013, 4, 31-50.

10. Levänen, J.; Hossain, M.; Lyytinen, T.; Hyvärinen, A.; Numminen, S.; Halme, M. Implications of Frugal Innovations on Sustainable Development: Evaluating Water and Energy Innovations. Sustainability 2016, 8 , 4. [CrossRef]

11. Littig, B.; Grießler, E. Social sustainability: A catchword between political pragmatism and social theory. Int. J. Sustain. Dev. 2005, 8, 65-79.

12. Bound, K.; Thornton, I.W. Our Frugal Future: Lessons from India's Innovation System; Nesta: London, UK, 2012.

13. Zeschky, M.; Widenmayer, B.; Gassmann, O. Frugal Innovation in Emerging Markets: The Case of Mettler Toledo. Res. Technol. Manag. 2011, 54, 38-45. [CrossRef]

14. Zeschky, M.B.; Winterhalter, S.; Gassmann, O. From Cost to Frugal and Reverse Innovation: Mapping the Field and Implications for Global Competitiveness. Res. Technol. Manag. 2014, 57, $20-27$.

15. Trott, P. Innovation Management and New Product Development, 4th ed.; Pearson Education Ltd.: Essex, UK, 2008.

16. Radjou, N.; Prabhu, J. Frugal Innovation: How to Do More with Less, 1st ed.; Profile Books Ltd.: London, UK, 2014.

17. Sharma, A.; Iyer, G.R. Resource-constrained product development: Implications for green marketing and green supply chains. Ind. Mark. Manag. 2012, 41, 599-608. [CrossRef]

18. Tiwari, R.; Herstatt, C. Assessing India's lead market potential for cost-effective innovations. J. Indian Bus. Res. 2012, 4, 97-115. [CrossRef]

19. Woolridge, A. The World Turned Upside Down. Economist 2010. Available online: http:/ /www.economist. com/node/15879369 (accessed on 20 March 2016).

20. Immelt, J.R.; Govindarajan, V.; Trimble, C. How GE is disrupting itself. Harv. Bus. Rev. 2009, 87, 56-65. 
21. Bhatti, Y.A.; Ventresca, M. The Emerging Market for Frugal Innovation: Fad, Fashion, or Fit? 2012. Available online: http:/ / papers.ssrn.com/sol3/papers.cfm?abstract_id=2005983 (accessed on 3 March 2016).

22. Hart, S.; Christensen, C.M. The great leap. Driving innovation from the Base of the Pyramid. MIT Sloan Manag. Rev. 2002, 44, 51-56.

23. Christensen, C.M.; Baumann, H.; Ruggles, R.; Sadtler, T.M. Disruptive innovation for social change. Harv. Bus. Rev. 2006, 84, 94-101. [PubMed]

24. Schuh, G.; Lenders, M.; Hieber, S. Lean Innovation-Introducing Value Systems to Product Development. Int. J. Innov. Techol. Manag. 2011, 8, 41-54. [CrossRef]

25. Prahalad, C.K.; Hart, S.L. The Fortune at the Bottom of the Pyramid. Strategy+Business, 2002. Available online: http://www.cs.berkeley.edu/ brewer/ict4b/Fortune-BoP.pdf (accessed on 15 March 2016).

26. Radjou, N.; Prabhu, J.; Ahuja, S. Jugaad Innovation: Think Frugal, Be Flexible, Generate Breakthrough Growth; Jossey-Bass: San Francisco, CA, USA, 2012.

27. Smith, A.; Fressoli, M.; Thomas, H. Grassroots innovation movements: Challenges and contributions. J. Clean. Prod. 2014, 63, 114-124. [CrossRef]

28. George, G.; McGahan, A.M.; Prabhu, J.; Macgahan, A. Innovation for inclusive growth: Towards a theoretical framework and a research agenda. J. Manag. Stud. 2012, 49, 662-683. [CrossRef]

29. Tiwari, R.; Herstatt, C. Frugal Innovation: A Global Networks' Perspective in Die Unternehmung. Swiss J. Bus. Res. Pract. 2012, 66, 245-274.

30. Simula, H.; Hossain, M.; Halme, M. Frugal and Reverse Innovations-Quo Vadis? Curr. Sci. 2015, 109, 1-6. [CrossRef]

31. Govindarajan, V.; Ramamurti, R. Reverse innovation, emerging markets, and global Strategy. Glob. Strategy J. 2011, 1, 191-205. [CrossRef]

32. Govindarajan, V.J.; Trimble, C. Reverse Innovation: Create Far from Home, Win Everywhere; Harvard Business Review Press: Boston, MA, USA, 2012.

33. Govindarajan, V. Reverse innovation playbook. Strateg. Direct. 2012, 28, 3. [CrossRef]

34. Agarwal, N.; Brem, A. Frugal and Reverse Innovation-Literature Overview and Case Study Insights from a German MNC in India and China. In Proceedings of the 2012 18th International Conference on Engineering, Technology and Innovation, Munich University of Applied Sciences, Munich, Germany, 18-20 June 2012; Katzy, B., Holzmann, T., Sailer, K., Thoben, K.D., Eds.; Strascheg Center for Entrepreneurship (SCE): Munich, Germany, 2012.

35. Zeschky, M.; Widenmayer, B.; Gassmann, O. Organising for reverse innovation in Western MNCs: The role of frugal product innovation capabilities. Int. J. Technol. Manag. 2014, 64, 255-275. [CrossRef]

36. Zedtwitz, M.; Corsi, S.; Søberg, P.V.; Frega, R. A typology of reverse innovation. J. Prod. Innov. Manag. 2015, 32, 12-28. [CrossRef]

37. Bobel, I. Jugaad: A New Innovation Mindset. J. Bus. Financ. Aff. 2012, 1, e116. [CrossRef]

38. Birtchnell, T. Jugaad as systemic risk and disruptive innovation in India. Contemp. South Asia 2011, 19, 357-372. [CrossRef]

39. Krishnan, R. From Jugaad to Systematic Innovation: The Challenge for India; Utpreraka Foundation: Bangalore, India, 2010.

40. Brem, A.; Wolfram, P. Research and development from the bottom up-introduction of terminologies for new product development in emerging markets. J. Innov. Entrep. 2014, 3, 1-22. [CrossRef]

41. Singh, R.; Gupta, V.; Mondal, A. Jugaad-From 'Making Do' and 'Quick Fix' to an Innovative, Sustainable and Low-Cost Survival Strategy at the Bottom of the Pyramid. Int. J. Rural. Manag. 2012, 8, 87-105. [CrossRef]

42. Prahalad, C.K. The Fortune at the Bottom of the Pyramid: Eradicating Poverty through Profits, 2nd ed.; Pearson Education: Upper Saddle River, NJ, USA, 2010.

43. Choi, C.J.; Kim, S.W.; Kim, J.B. Globalizing Business Ethics Research and the Ethical Need to Include the Bottom-of-the-Pyramid Countries: Redefining the Global Triad as Business Systems and Institutions. J. Bus. Ethics 2010, 9, 299-306. [CrossRef]

44. Mair, J.; Marti, I.; Ventresca, M.J. Building Inclusive Markets in Rural Bangladesh: How Intermediaries Work Institutional voids. Acad. Manag. J. 2012, 55, 819-850. [CrossRef]

45. Pitta, D.A.; Guesalaga, R.; Marshall, P. The quest for the fortune at the bottom of the pyramid: Potential and challenges. J. Consum. Mark. 2008, 25, 393-401. [CrossRef] 
46. Mahajan, V. Africa Rising: How 900 Million African Consumers Offer More Than You Think; Wharton School Publishing: Upper Saddle River, NJ, USA, 2009.

47. Mahajan, V.; Banga, K.; Gunther, R. The 86 Percent Solution: How to Succeed in the Biggest Market Opportunity of the Next 50 Years; Wharton School Publishing: Upper Saddle River, NJ, USA, 2006.

48. Abayomi, B.; Jaspar, R. Disruptive Innovations at the Bottom of the Pyramid: Can they impact on the sustainability of today's companies? In Proceedings of the Trends and Future of Sustainable Development Conference, Tampere, Finland, 9-10 June 2011; pp. 325-336.

49. Karnani, A. The Mirage of Marketing to the Bottom of the Pyramid: How the Private Sector can help Alleviate Poverty. Calif. Manag. Rev. 2007, 49, 90-112. [CrossRef]

50. London, T. Making Better Investments at the Base of the Pyramid. Harv. Bus. Rev. 2009, 87, 106-113.

51. London, T.; Hart, S.T. Reinventing strategies for emerging markets: Beyond the Transnational Model. J. Int. Bus. Stud. 2004, 35, 350-370. [CrossRef]

52. Pansera, M.; Sarkar, S. Crafting Sustainable Development Solutions: Frugal Innovations of Grassroots Entrepreneurs. Sustainability 2016, 8, 51. [CrossRef]

53. Hall, J.; Matos, S.; Sheehan, L.; Silvestre, B. Entrepreneurship and Innovation at the Base of the Pyramid: A Recipe for Inclusive Growth or Social Exclusion? J. Manag. Stud. 2012, 49, 785-812. [CrossRef]

54. Khavul, S.; Bruton, G.D. Harnessing Innovation for Change: Sustainability and Poverty in Developing Countries. J. Manag. Stud. 2013, 50, 285-306. [CrossRef]

55. Prahalad, C.K. Bottom of the Pyramid as a Source of Breakthrough Innovations. J. Prod. Innov. Manag. 2012, 29, 6-12. [CrossRef]

56. Prahalad, C.K.; Mashelkar, R.A. Innovation's Holy Grail. Harv. Bus. Rev. 2010, 88, 132-141.

57. Kandachar, P.; Halme, M. Introduction: An Explanatory Journey towards the Research and Practice of the Base of the Pyramid. Green. Manag. Int. 2007, 51, 3-17. [CrossRef]

58. Paton, B.; Halme, M. Bringing the needs of the poor into the BOP debate. Bus. Strategy Environ. 2007, 16, 585-586. [CrossRef]

59. Pervez, T.; Maritz, A.; Waal, A. Innovation and Social Entrepreneurship at the bottom of the pyramid-A Conceptual Framework. S. Afr. J. Econ. Manag. Sci. 2013, 16, 54-66.

60. Prahalad, C.K. The innovation sandbox. Strategy+Business, 2006. Available online: http://www.strategybusiness.com/media/file/sb44_06306.pdf (accessed on 10 February 2016).

61. Anderson, J.; Markides, C. Strategic Innovation at the Base of the Pyramid. MIT Sloan Manag. Rev. 2007, 49, 83-88.

62. Agnihotri, A. Revisiting the Debate over the Bottom of the Pyramid Market. J. Macromark. 2012, 32, 417-423. [CrossRef]

63. Gupta, A.K. Grassroot Green Innovations for Inclusive, Sustainable Development. In The Innovation for Development Report 2009-2010: Strengthening Innovation for the Prosperity of Nations; López-Carlos, A., Ed.; Palgrave Macmillan: Hampshire, UK, 2010; pp. 137-146.

64. Gupta, A. Innovations for the poor by the poor. Int. J. Technol. Learn. Innov. Dev. 2012, 5, 28-39. [CrossRef]

65. Kolk, A.; Rivera-Santos, M.; Rufin, C. Reviewing a Decade of Research on the 'Base/Bottom of the Pyramid' (BOP) Concept. Bus. Soc. 2013, 20, 1-40. [CrossRef]

66. Karnani, A. The Bottom of the Pyramid Strategy for Reducing Poverty: A Failed Promise. In Poor Poverty: The Impoverishment of Analysis; Sundaram, J.K., Chowdhury, A., Eds.; DESA, Bloomsbury Academic and United Nations: London, UK, 2011.

67. Karnani, A. Misfortune at the Bottom of the Pyramid. Green. Manag. J. 2007, 51, 99-110. [CrossRef]

68. Karnani, A. Doing Well by Doing Good: The Grand Illusion. Calif. Manag. Rev. 2011, 53, 69-86. [CrossRef]

69. Arora, S.; Romijn, H. The empty rhetoric of poverty reduction at the base of the pyramid. Organization 2011, 19, 481-505. [CrossRef]

70. Basu, R.R.; Banerjee, P.M.; Sweeny, E.G. Frugal Innovation: Core Competencies to address Global Sustainability. J. Manag. Glob. Sustain. 2013, 1, 63-82. [CrossRef]

71. Prathap, G. The myth of frugal innovation in India. Curr. Sci. 2014, 106, 374-377.

72. Inno. Post. What Everybody Ought to Know about Frugal Innovation. Available online: http://www. innovation-post.com/what-everybody-ought-to-know-about-frugal-innovation/\#sthash.5iIrDjFs.dpuf (accessed on 21 March 2016).

73. Rao, B.C. How disruptive is frugal? Technol. Soc. 2013, 35, 65-73. [CrossRef] 
74. Mukerjee, K. Frugal Innovation: The Key to Penetrating Emerging Markets. Available online: http:/ /iveybusinessjournal.com/publication/frugal-innovation-the-key-to-penetrating-emerging-markets / (accessed on 19 March 2016).

75. Bhatti, Y. What Is Frugal, What Is Innovation? Towards a Theory of Frugal Innovation. 2012. Available online: http:/ / ssrn.com/abstract=2005910 (accessed on 6 May 2016).

76. Lim, C.; Han, S.; Ito, H. Capability building through innovation for unserved lower end mega markets. Technovation 2013, 3, 391-404. [CrossRef]

77. Soni, P.; Krishnan, R.T. Frugal innovation: Aligning theory, practice, and public policy. J. Indian Bus. Res. 2013, 6, 29-47. [CrossRef]

78. Angot, J.; Ple, L. Serving poor people in rich countries: The bottom-of-the-pyramid business model solution. J. Bus. Strategy 2015, 36, 3-15. [CrossRef]

79. Schlossberg, M.; Zimmerman, A. Developing Statewide Indices of Environmental, Economic and Social Sustainability: A look at Oregon and the Oregon Benchmarks. Local Environ. 2003, 8, 641-660. [CrossRef]

80. Lozano, R. Envisioning sustainability three-dimensionally. J. Clean. Prod. 2008, 16, 1838-1846. [CrossRef]

81. Moldan, B.; Janouskova, S.; Hak, T. How to understand and measure environmental sustainability: Indicators and targets. Ecol. Indic. 2012, 17, 4-13. [CrossRef]

82. Cuthill, M. Strengthening the 'social' in sustainable development: Developing a conceptual framework for social sustainability in a rapid urban growth region in Australia. Sustain. Dev. 2009, 18, 362-373. [CrossRef]

83. Missimer, M.; Robert, K.H.; Broman, G.; Sverdrup, H. Exploring the possibility of a systematic and generic approach to social sustainability. J. Clean. Prod. 2010, 18, 1107-1112. [CrossRef]

84. Spangenberg, J.H.; Omann, I. Assessing social sustainability: Social sustainability and its multicriteria assessment in a sustainability scenario for Germany. Int. J. Innov. Sustain. Dev. 2006, 1, 318-348. [CrossRef]

85. Koning, J. Social sustainability in a globalizing world context, theory and methodology explored. In Proceedings of the UNESCO/MOST Meeting, The Hague, The Netherlands, 22-23 November 2001.

86. Vifell, A.C.; Soneryd, L. Organizing matters: How 'the social dimension' gets lost in sustainability projects. Sustain. Dev. 2012, 20, 18-27. [CrossRef]

87. Woodcraft, S. Social Sustainability and New Communities: Moving from concept to practice in the UK Procedia. Soc. Behav. Sci. 2012, 68, 29-42. [CrossRef]

88. Vifell, A.C.; Thedvall, R. Organizing for social sustainability: Governance through bureaucratization in meta-organizations. Sustain. Sci. Pract. Policy 2012, 8, 50-58.

89. Colantonio, A. Social sustainability: Exploring the linkages between research, policy and practice. In European Research on Sustainable Development: Transformative Science Approaches for Sustainability; Jaeger, C.C., Tabara, J.D., Jaeger, J., Eds.; Springer: Berlin, Germany, 2011; pp. 35-58.

90. Colantonio, A. Social Sustainability: An Exploratory Analysis of Its Definition, Assessment Methods Metrics and Tools; EIBURS Working Paper 2007/01; Oxford Institute for Sustainable Development (OISD), Oxford Brooks University: Oxford, UK, 2007.

91. Weingaertner, C.; Moberg, Å. Exploring social sustainability: Learning from perspectives on urban development and companies and products. Sustain. Dev. 2014, 22, 122-133. [CrossRef]

92. Mak, M.Y.; Peacock, C.J. Social sustainability: A comparison of case studies in UK, USA and Australia. In Proceedings of the 17th Pacific Rim Real Estate Society Conference, PRRES, Gold Coast, Australia, 16-19 January 2011.

93. Davidson, M. Social sustainability: A potential for politics? Local Environ. 2009, 14, 607-619. [CrossRef]

94. Dempsey, N.; Bramley, G.; Power, S.; Brown, C. The social dimension of sustainable development: Defining urban social sustainability. Sustain. Dev. 2011, 19, 289-300. [CrossRef]

95. Landorf, C. Evaluating social sustainability in historic urban environments. Int. J. Herit. Stud. 2011, 17, 463-477. [CrossRef]

96. Ghahramanpouri, A.; Lamit, H.; Sedaghatnia, S. Urban Social Sustainability Trends in Research Literature. Asian Soc. Sci. 2013, 9, 185-193. [CrossRef]

97. Bacon, N. Social sustainability and new communities: Moving from concept to practice in the UK. In Future Communities: Socio-Cultural and Environmental Challenges 2012; The Berkeley Group: Giza, Egypt, 2012; pp. 29-42. 
98. Sachs, I. Social Sustainability and Whole Development: Exploring the Dimensions of Sustainable Development. In Sustainability and the Social Sciences: A Cross-Disciplinary Approach to Integrating Environmental Considerations into Theoretical Reorientation; Egon, B., Thomas, J., Eds.; Zed Books: London, UK, 1999.

99. Polese, M.; Stren, R. The Social Sustainability of Cities: Diversity and the Management of Change; University of Toronto Press: Toronto, ON, Canada, 2000.

100. McKenzie, S. Social Sustainability: Towards Some Definitions; Working Paper No. 27; Hawk Research Institute, University of South Australia: Magill, Australia, 2004.

101. Chiu, R. Social Sustainability, Sustainable Development and Housing Development: The Experience of Hongkong. In Housing and Social Change: East, West Perspectives; Forrest, R., Lee, J., Eds.; Routledge: London, UK, 2003; pp. 221-239.

102. Colantonio, A. Urban social sustainability themes and assessment methods. Proc. Inst. Civ. Eng. Urban Des. Plan. 2010, 163, 79-88. [CrossRef]

103. Glasson, J.; Wood, G. Urban regeneration and impact assessment for social sustainability. Impact Assess. Proj. Apprais. 2009, 27, 283-290. [CrossRef]

104. Vallance, S.; Perkins, H.C.; Dixon, J.E. What is social sustainability? A clarification of concepts. Geoforum 2011, 42, 342-348. [CrossRef]

105. Missimer, M.; Robèrt, K.-H.; Broman, G. A Strategic Approach to Social Sustainability—Part 1: Exploring the Social System. J. Clean. Prod. 2016, in press.

106. Magis, K.; Shinn, C. Emergent themes of social sustainability. In Understanding the Social Aspect of Sustainability; Dillard, J., Dujon, V., King, M.C., Eds.; Routledge: New York, NY, USA, 2009; pp. 1-16.

107. Larsen, G. An inquiry into the theoretical basis of sustainability: Ten propositions. In Understanding the Social Aspect of Sustainability; Dillard, J., Dujon, V., King, M.C., Eds.; Routledge: New York, NY, USA, 2009; pp. 45-83.

108. Assefa, G.; Frostell, B. Social Sustainability and Social Acceptance in technology Assessment: A Case Study of Energy Technologies. Technol. Soc. 2007, 29, 63-78. [CrossRef]

109. Burton, E. Housing for an urban renaissance: Implications for social equity. Hous. Stud. 2003, 18, 537-562. [CrossRef]

110. Geibler, J.; Liedtke, C.; Wallbaum, H.; Schaller, S. Accounting for the Social Dimension of Sustainability: Experiences from the Biotechnology Industry. Bus. Strategy Environ. 2006, 15, 334-346. [CrossRef]

111. Labuschagne, C.; Brent, A.C. Social Indicators for Sustainable Project and Technology Life Cycle Management in the Process Industry. Int. J. Life Cycle Assess. 2006, 11, 3-15.

112. Grieco, M. Social sustainability and urban mobility: Shifting to a socially responsible pro-poor perspective. Soc. Responsib. J. 2014, 11, 82-97. [CrossRef]

113. Bebbington, J.; Dillard, J. Social sustainability: An Organizational-Level Analysis. In Understanding the Social Aspect of Sustainability; Dillard, J., Dujon, V., King, M.C., Eds.; Routledge: New York, NY, USA, 2009; pp. 157-173.

114. Tirado, A.A.; Morales, M.R.; Lobato-Calleros, O. Additional Indicators to Promote Social Sustainability within Government Programs: Equity and Efficiency. Sustainability 2015, 7, 9251-9267. [CrossRef]

115. Wolbring, G.; Rybchinski, T. Social Sustainability and its Indicators through a Disability Studies lens and an Ability Studies lens. Sustainability 2013, 5, 4889-4907. [CrossRef]

116. Missimer, M.; Robèrt, K.H.; Broman, G. A strategic approach to social sustainability-Part 2: A principle-based definition. J. Clean. Prod. 2016, in press.

117. Holliday, C.O.; Schmidheiny, S.; Watts, P. Walking the Talk: The Business Case for Sustainable Development; Greenleaf Publishing: Sheffield, UK, 2002.

118. Visser, W.; Sunter, C. Beyond Reasonable Greed: Why Sustainable Business Is a Much Better Idea; Human \& Rousseau Tafelberg: Cape Town, South Africa, 2002.

119. Pfeffer, J. Building Sustainable Organizations: The Human Factor. Acad. Manag. Perspect. 2010, $24,34-45$. [CrossRef]

120. Hutchins, M.J.; Sutherland, J.W. An exploration of measures of social sustainability and their application to supply chain decisions. J. Clean. Prod. 2008, 16, 1688-1698. [CrossRef]

121. Suopajärvi, L.; Poelzer, G.A.; Ejdemo, T.; Klyuchnikova, E.; Korchak, E.; Nygaard, V. Social sustainability in northern mining communities: A study of the European North and Northwest Russia. Resour. Policy 2016, 47, 61-68. [CrossRef] 
122. Vasquez, R.V.; Klotz, L.E. Social Sustainability Considerations during Planning and Design: Framework of Processes for Construction Projects. J. Constr. Eng. Manag. 2013, 139, 80-89. [CrossRef]

123. Huq, F.A.; Stevenson, M.; Zorzini, M. Social sustainability in developing country suppliers. Int. J. Oper. Prod. Manag. 2014, 34, 610-638.

124. Lindgreen, A.; Antioco, M.; Harness, D.; van Sloot, R. Purchasing and Marketing of Social and Environmental Sustainability for High-Tech Medical Equipment. J. Bus. Ethics 2009, 85, 445-462. [CrossRef]

125. Brown, D.; Dillard, J.; Marshall, R.S. Triple Bottom Line: A Business Metaphor for a Social Construct; School of Business Administration, Portland State University: Portland, OR, USA, 2006.

126. Magee, L.; Scerri, A.; James, P.; Thom, J.A.; Padgham, L.; Hickmott, S.; Deng, H.; Cahill, F. Reframing social sustainability reporting: Towards an engaged approach. Environ. Dev. Sustain. 2013, 15, 225-243. [CrossRef]

127. Nunes, M.F.; Park, C.L. Self-claimed sustainability: Building social and environmental reputations with words. Sustain. Prod. Consum. 2016, in press.

128. Labuschagne, C.; Brent, A.C.; van Erck, R.P.G. Assessing the sustainability performances of industries. J. Clean. Prod. 2005, 13, 373-385. [CrossRef]

129. McElroy, M.W.; Jorna, R.J.; van Engelen, J. Sustainability Quotients and the Social Footprint. Corp. Soc. Responsib. Environ. Mgmt. 2008, 15, 223-234. [CrossRef]

130. Thomsen, K.; King, M.C. Working out Social Sustainability on the Ground. In Understanding the Social Aspect of Sustainability; Dillard, J., Dujon, V., King, M.C., Eds.; Routledge: New York, NY, USA, 2009; pp. 199-210.

131. Measuring Impact: Subject Paper of the Impact Measurement Working Group. Available online: http:/ / www. socialimpactinvestment.org/reports/Measuring\%20Impact\%20WG\%20paper\%20FINAL.pdf (accessed on 28 September 2016).

132. So, I.; Staskevicius, A. Measuring the Impact in Impact Investing. Available online: http://www.hbs.edu/ socialenterprise/Documents/MeasuringImpact.pdf (accessed on 27 September 2016).

133. Best, H.; Harji, K. Guidebook for Impact Investors: Impact Measurement. Available online: http:/ / purposecap. com/wp-content/uploads/Purpose-Capital-Guidebook-for-Impact-Investors-Impact-Measurement.pdf (accessed on 28 September 2016).

134. Galuppo, L.; Gorli, M.; Scaratti, G.; Kaneklin, C. Building social sustainability: Multi-stakeholder processes and confiict management. Soc. Responsib. J. 2014, 10, 685-701. [CrossRef]

135. Funk, K. Sustainability and Performance. MIT Sloan Manag. Rev. 2003, 44, 65-70.

136. Fisk, P. People, Planet, Profit: How to Embrace Sustainability for Innovation and Business Growth; Kogan Page Limited: London, UK, 2010.

137. Boström, M. A missing pillar? Challenges in theorizing and practicing social sustainability: Introduction to the special issue. Sustain. Sci. Pract. Policy 2012, 8, 1-12.

138. Castillo, H.; Price, A.; Moobela, C.; Mathur, V. Assessing urban social sustainability: Current capabilities and opportunities for future research. Int. J. Environ. Cult. Econ. Soc. Sustain. 2007, 3, 39-48. [CrossRef]

139. Gauthier, C. Measuring Corporate Social and Environmental Performance: The Extended Life-Cycle Assessment. J. Bus. Ethics. 2005, 59, 199-206. [CrossRef]

140. Tanzil, D.; Beloff, B. Assessing Impacts: Overview on Sustainability Indicators and Metrics: Tools for Implementing Sustainable Development in the Chemical Industry, and Elsewhere. J. Environ. Qual. 2006, 15, 41-56. [CrossRef]

141. Colantonio, A.; Dixon, T. Urban Regeneration and Social Sustainability: Best Practice from European Cities; Wiley-Blackwell: Chichester, UK, 2011.

142. Rogers, D.S.; Duraiappah, A.K.; Antons, D.C.; Munoz, P.; Bai, X.; Fragkias, M.; Gutscher, H. A vision for human well-being: Transition to social sustainability. Curr. Opin. Environ. Sustain. 2012, 4, 61-73. [CrossRef]

143. Baines, J.; Morgan, B. Sustainability Appraisal: A Social Perspective. In Sustainability Appraisal. A Review of International Experience And Practice; Dalal-Clayton, B., Sadler, B., Eds.; First Draft of Work in Progress; International Institute for Environment and Development: London, UK, 2004.

144. Ancell, S.; Thompson-Fawcett, M. The social sustainability of medium density housing: A conceptual model and Christchurch case study. Hous. Stud. 2008, 23, 423-442. [CrossRef]

145. Carew, A.L.; Mitchell, A.A. Teaching sustainability as a contested concept: Capitalizing on variation in engineering educators' conceptions of environmental, social and economic sustainability. J. Clean. Prod. 2008, 16, 105-115. [CrossRef] 
146. Murphy, K. The Social Pillar of Sustainable Development: A Literature Review and Framework for Policy Analysis. Sustain. Sci. Pract. Policy 2012, 8, 15-29.

147. Giddings, B.; Hopwood, B.; O'Brien, G. Environment, Economy and Society: Fitting them Together into Sustainable Development. Sustain. Dev. 2002, 10, 187-196. [CrossRef]

148. Chambers, R.; Conway, G.R. Sustainable Rural Livelihoods: Practical Concepts for the 21st Century; IDS Discussion Paper 296; Institute of Development Studies: Brighton, UK, 1992.

149. Thin, N.; Lockhart, C.; Yaron, G. Conceptualising Socially Sustainable Development. Unpublished work, 2002.

150. Holden, M. Urban Policy Engagement with Social Sustainability in Metro Vancouver. Urban Stud. 2012, 49, 527-542. [CrossRef] [PubMed]

151. Ketschau, T.J. Social Justice as a Link between Sustainability and Educational Sciences. Sustainability 2015, 7, 15754-15771. [CrossRef]

152. Davidson, K.; Wilson, L. A Critical Assessment of Urban Social Sustainability; Working Paper; The University of South Australia: Adelaide, Australia, 2009.

153. Bramley, G.; Power, S. Urban form and social sustainability: The role of density and housing type. Environ. Plan. B Plan. Des. 2009, 36, 30-48. [CrossRef]

154. Chan, E.; Lee, K. Critical factors for improving social sustainability of urban renewal projects. Soc. Indic. Res. 2008, 85, 243-256. [CrossRef]

155. Magis, K. Community resilience: An indicator of social sustainability. Soc. Nat. Resour. 2010, 23, 401-416. [CrossRef]

156. Messer, W.B.; Kecskes, K. Social Capital and Community: University Partnerships. In Understanding the Social Aspect of Sustainability; Dillard, J., Dujon, V., King, M.C., Eds.; Routledge: New York, NY, USA, 2009; pp. 248-263.

157. Semenza, J.C. Advancing Social Sustainability: An Intervention Approach. In Understanding the Social Aspect of Sustainability; Dillard, J., Dujon, V., King, M.C., Eds.; Routledge: New York, NY, USA, 2009; pp. $264-282$.

158. Rogers, S.; Gardner, K.; Carlson, C. Social capital and walkability as social aspects of sustainability. Sustainability 2013, 5, 3473-3483. [CrossRef]

159. El-Husseiny, M.; Kesseiba, K. Challenges of Social Sustainability in Neo-liberal Cairo: Requestioning the role of public space. Procedia Soc. Behav. Sci. 2012, 68, 790-803. [CrossRef]

160. Rocak, M.; Hospers, G.; Reverda, N. Searching for Social Sustainability: The Case of the Shrinking City of Heerlen, The Netherlands. Sustainability 2016, 8, 382. [CrossRef]

161. O'Hara, S.U. Community based urban development: A strategy for improving social sustainability. Int. J. Soc. Econ. 1999, 26, 327-1343. [CrossRef]

162. Bramley, G.; Demsey, N.; Power, S.; Brown, C. What is Social Sustainability and how do our existing urban forms perform in nurturing it? In Proceedings of the Planning Research Conference, Bartlett School of Planning, UCL, London, UK, 5-7 April 2006.

163. Yung, E.H.K.; Chan, E.H.W.; Xu, Y. Sustainable Development and the Rehabilitation of a Historic Urban District-Social Sustainability in the Case of Tianzifang in Shanghai. Sustain. Dev. 2011, 22, 95-112. [CrossRef]

164. Yung, H.K.E.; Chan, H.W.E. Critical social sustainability factors in urban conservation: The case of the central police station compound in Hong Kong. Facilities 2012, 30, 396-416. [CrossRef]

165. Woodcraft, S.; Hackett, T.; Caistor-Arendar, L. Design for Social Sustainability: A Framework for Creating Thriving New Communities; Young Foundation: London, UK, 2011.

166. Aravind Eye Care System. Available online: http://www.aravind.org/ (accessed on 3 April 2016).

167. Kumar, S. Kerala, India, A regional community-based palliative care model. J. Pain Symptom Manag. 2007, 33, 623-627. [CrossRef] [PubMed]

168. Vortex. Available online: http://vortexindia.co.in/ (accessed on 21 February 2016).

169. SELCO: Solar Lighting for the Poor. Available online: http://www.growinginclusivemarkets.org/media/ cases/India_SELCO_2011.pdf (accessed on 19 March 2016).

170. Solar Electric Light Company, India (SELCO). Available online: http://www.selco-india.com/pdfs/ corporate_brochure_selco.pdf (accessed on 19 March 2016).

171. Hughes, N.; Lonie, S. "M-PESA: Mobile Money for the unbanked," Turning Cellphones into 24-Hour Tellers in Kenya. Innov. Technol. Gov. Glob. 2007, 2, 63-81. [CrossRef]

172. Jack, W.; Suri, T. The Economics of M-PESA. 2011. Available online: http://www.mit.edu/ tavneet/M-PESA.pdf (accessed on 26 September 2016). 
173. Buku, M.W.; Meredith, M.W. Safaricom and M-PESA in Kenya: Financial Inclusion and Financial Integrity. Wash. JL Tech. Arts 2013, 8, 375-399.

174. Schmidt, J. Craftskills East Africa Limited. In Cases with a Conscience: Entrepreneurial Solutions to Global Challenges; Dean, T.J., Birnbaum, M.D.M., Eds.; Sustainable Venturing Press: Boulder, CO, USA, 2009; pp. 83-89.

175. Adriaens, P.; de Lange, D. Field Structuration around New Issues: Clean Energy Entrepreneurialism in Emerging Economies. 2012. Available online: https://deepblue.lib.umich.edu/bitstream/handle/2027.42/ 94215/1180_Adriaens.pdf?sequence=1\&isAllowed=y (accessed on 26 September 2016).

176. Sustainability through Frugality. Available online: http://newglobal.aalto.fi/sustainability-through-frugality/ (accessed on 26 September 2016).

(C) 2016 by the author; licensee MDPI, Basel, Switzerland. This article is an open access article distributed under the terms and conditions of the Creative Commons Attribution (CC-BY) license (http://creativecommons.org/licenses/by/4.0/). 